\title{
On the nature of national involvement: a preliminary study ${ }^{1}$
}

\author{
JOHN DELAMATER, University of Michigan
}

DANIEL KATZ, University of Michigan

and HERBERT C. KELMAN, Harvard University

The recent revival of interest in problems of nationalism among social scientists has several sources. Nationalistic rivalries hold more threat than ever because of the development of the technology of destruction. Within our own nation the emergence of radical right movements and the related ideology of super-patriotism produce pressures for a more aggressive foreign policy. On the other hand, for the emerging nations, nationalism is often seen as a positive unifying force in overcoming tribal rivalries.

\section{National Involvement}

The core referent of the concept of nationalism appears to be an individual's emo-

1 This paper is part of a research program on national role involvement sponsored by the Center for Research on Conflict Resolution at the University of Michigan. Additional financial support for the study reported here was provided by Public Health Service Research Grant MH-07280-07 from the National Institute of Mental Health for a research program on social influence and behavior change (Herbert C. Kelman, principal investigator). We are indebted to Richard Flacks who collaborated with us in the original formulation of the project and who initiated the study reported here. We are also grateful to Mark Chesler for his valuable assistance in the initial phase of the study. tional attachment to his nation or country which leads him to desire more power for it. The concept thus refers to one form of involvement of an individual in his country's affairs and to the ideology associated with it. However, it has weaknesses as an adequate concept for two reasons. First, the term is subject to value-laden interpretations, based on the popularly perceived desirability of patriotism on the one hand and the undesirability of chauvinism and jingoism on the other. Second, it is apparent that nationalism is only one aspect of the broader problem of how individuals relate to the nation-state, how they are integrated into it, and how this integration affects their attitudes, values, and behavior.

From a scientific point of view, the relationship of the individual to his country can be studied at two levels, the socialsystem level and the social-psychological level. At the system level, one would be concerned with the prevailing ideology that defines this relationship, and with the effects on this ideology of the country's international environment and of the basic functional problems facing it at that point in time. One could investigate such problems by analyzing documents and pronounce- 
ments of national leaders, and relating these to various institutional arrangements and to the values transmitted by these institutions.

At the social-psychological level, the focus is shifted to the individual and his immediate social environment. Here one is primarily concerned with the individual's view of his relation to the nation-state-his beliefs concerning his obligations to the system and vice versa, the mechanisms that involve him in the system, and the attitudes and values he holds as a function of this involvement. It is assumed that there will be some general components of this ideology that are held by all or most members of the system; these would presumably be a function of the nature of the state itself. But there will also be variation across individuals, e.g., in the intensity of their commitment, the components of the ideology that they emphasize, or the type of mechanism that binds them into the system. These variations might be a function of various demographic factors, of position in the political structure, and of personality variables.

A concept that allows one to integrate the system level of analysis and the socialpsychological level is the role of national. Thus, one can conceive of the nation-state as a system of roles, and of each individual as enacting a particular role within this system. At the system level, the national ideology (which justifies the existence of the system) defines the appropriate role behaviors for members (i.e., sets expectations), specifies the conditions under which such behaviors are required, and designates various attitudes and values as valid. This ideology is built into and/or manifested by political institutions, especially the legal system; it is communicated by those holding high positions in the national system, and transmitted to individuals via mass media and socializing agencies.
At the same time, a role-definition can be viewed as a characteristic of the individual, acquired in the course of his socialization. One can investigate his definition of the national role and his expectations concerning appropriate behavior and attitudes relative to those held by other nationals. One can also study his role enactment: the salience of the role for him, the cues he responds to, the behaviors he performs, and the strength of his commitment to the role. One would expect different segments of the society to differ in their conception of what is expected of them as nationals and in their actual behavior as a function of their different positions in the role system. Thus the concept of role allows one to analyze both constancies and variations at both the system and social-psychological levels. ${ }^{2}$

The study to be reported here focuses on the social-psychological level of analysis. The system level is discussed only where it illuminates our findings concerning individuals.

In sum, we conceive of national involvement as a role relationship between the person and the nation. From the point of view of the individual, the national role consists of his expectations about the way in which he and others within the society should behave with respect to the maintenance and welfare of the nation. It is assumed that these expectations will vary as a function of

2 It should be noted that, in discussing the role of a national, we are focusing only on the individual's relationship to the political system or state. We are not concerned here with the problem of his relationship to the national culture and its common language, history, and tradition. A complete analysis of the relationship between individual and nation would also consider his ties to this cultural system, i.e., his cultural identification with the nation, and the reciprocal relations between the cultural and political systems within the nation ( $\mathrm{cf}$. Kelman, 1969). 
the individual's position in the role system that is the nation-state.

\section{MODES OF SYSTEM INTEGRATION}

Following Katz and Kahn (1966), we can distinguish three major means by which a role system is integrated: through values, norms, and roles.

Any role system is linked to a set of values which justifies its goals and continued operation. These values provide rationales for organizational activities, legitimacy for the demands the system makes on members, and symbolic rewards for membership and for members' positive contributions to system functioning. In the United States, for example, the value system centers around such concepts as democracy, equality before the law, and freedom in its various forms for all members of the nation-state. These values are usually closely associated with a variety of symbols which represent the nation and the national values themselves. In the United States, such symbols include the American flag, the national anthem, the Constitution, and the Presidency. To the extent that members are socialized to identify with these symbols and values, a strong source of system integration results.

The role system is elaborated through a set of norms that specify appropriate and inappropriate behaviors for those holding a given position within the system. These norms are specifications or "operational" statements of system values, and are typically established to ensure that those functions vital to system maintenance and success are performed. The norms are accompanied by a set of sanctions designed to reward conformity to them and punish deviation from them. These norms and sanctions constitute a second source of integration to the extent that they induce appropriate behaviors.

Finally, a system is integrated through the interdependencies created by the role structure itself. The rewards obtained by each member depend not only on his own role performance, but on satisfactory performance by others whose roles are reciprocal to his. This mutual interdependence creates a strong motivation for each member to meet the expectations that go with his role and thus to keep the system intact.

The functioning of any social system is closely related to the effectiveness of these mechanisms for producing integration. In most national systems the three modes reinforce each other. The demands of the national role are reinforced by norms and by related sanctions, and both the norms and the role requirements are justified by appeals to system values. But the emphasis given each mode may vary greatly across nations, and within the same nation over time (cf. Katz, Kelman, and Flacks, 1964).

\section{TYPES OF NATIONAL INVOLVEMENT}

Just as national role systems differ in the degree to which each mode of integration is present and/or emphasized, individual role players differ with respect to the manner in which they are involved in the national role. The types of individual involvement parallel the modes of system integration discussed above.

An individual may be symbolically integrated or committed to the national role. Such a commitment is characterized by a strong emotional investment in the nation and its values, and a positive affective orientation to its symbols. A symbolically integrated individual gives a high priority to his role as a national, and derives direct and intrinsic emotional satisfactions from his enactment of this role.

The second type is a normative commitment to the national role. It is characterized 
by an orientation toward the sanctions attached to the national role expectations as the individual perceives them. There is relatively little emotional investment in the role per se. The individual conforms to the roleexpectations because he accepts the system as equitable and because he anticipates negative consequences for failure to conform.

Third, the individual's commitment to the role may be a functional one. This commitment is based on an instrumental relationship to the ongoing system-on the rewards he perceives as the outcome of participation in the system. He views these rewards as important, and is committed to the system because he wishes to continue receiving them.

Finally, there are individuals who are alienated from the national system, for whom the national role is never positively salient nor enacted. For such persons, neither the emotional nor the material rewards derivable from enactment are sufficient to produce the behavior; similarly, the sanctions for failure to conform are not sufficiently threatening.

It is assumed that most members of the nation-state are motivated to adopt the national role, when appropriate, through one or more of these mechanisms. Also, each member is perhaps characterized by a primary involvement through one type. Whether his involvement is due to attachment to symbols and values, or concern with norms, or concern with the functional rewards of participation should depend on his socialization, his position in the social system, and the orientation of those social groups with which he is affiliated. Each type of involvement should be associated with different expectations about the appropriate role of a national, and with specific attitudes toward a variety of national and international issues.

\section{Hypotheses ${ }^{3}$}

The present formulation yields a number of specific predictions about the characteristics of individuals whose involvement in the national role is of a given type. Predictions can also be made about the content of the national role as perceived by each type of individual; these predictions represent a definitional specification of the typology presented above.

\section{SYMBOLIC COMMITMENT}

Americans whose commitment to the national role is primarily a symbolic one are expected to be characterized by the following attitudes:

(a) Strong positive affect for national symbols, such as the national anthem, the flag, and national leaders.

(b) Emphasis on the learning and enactment of the role of "American," as compared to other roles, e.g., occupational, religious, and community roles.

(c) Low tolerance for any behavior that deviates from perceived role prescriptions, or that places a greater priority on values viewed as incompatible with Americanism.

(d) Defensiveness against criticism of the American system or way of life.

(e) Readiness to deny civil liberties to those who advocate radical change.

(f) Hostility toward alien values and life styles; approval of actions that would extend the American way of life.

(g) Opposition to policies that would weaken American sovereignty, reduce national power, or reflect negatively on national honor.

There are certain similarities between these characteristics and Durkheim's conception of mechanical solidarity (cf. 1952). The present conception of functional integration in turn parallels his concept of organic solidarity. Symbolic commitment is prevalent during the early stages of the development

${ }^{3}$ The material in this section is based on Katz et al., 1964. 
of a nation, when many diverse ethnic groups, language communities, and interest groups must be united under a common system. Symbols are an effective way to achieve such integration. Much of what is presently occurring in many of the emerging African nations seems to fit this pattern. However, such integration appears to be relatively brittle in a changing society, and is less conducive to a truly stable system than is widespread functional integration, based on mutual dependence for the satisfaction of interests. As Durkheim noted, the transition to organic solidarity (i. e., functional interdependence) occurs with increasing specialization of roles in society; it is particularly hastened by bureaucratization. (For an elaboration, see Katz, 1965).

We therefore expect symbolic commitment to be weak in contemporary American society relative to normative and functional mechanisms. We would expect the principal cause of strong symbolic involvement in this country to be the experience or threat of a disruption of an individual's functional ties to the system, particularly if this disruption affects his central values, his status in the system, or his power. Symbolic commitment can thus be a means of reducing anxiety, of achieving a sense of identity and integration in a society that has become too complex and difficult to comprehend, or of restoring lost power.

Technology, bureaucratization, and managerialism in contemporary America have posed threats to the power of the old middle class. The traditional ties to the system of the individual entrepreneur, small businessman, and farmer have been disrupted by these developments. Such threats have also been felt by such groups as rural and smalltown dwellers, and fundamentalist Protestants. According to many observers (e.g., Bell, 1963), these social categories are heavily represented in the John Birch Society and similar super-patriot groups-organizations that constitute the purest case of symbolic commitment in America today. ${ }^{4}$ Many other people who fall into these categories may be characterized by a symbolic commitment, though they may not belong to ultra-right groups.

\section{NORMATIVE COMMITMENT}

Persons who are well integrated into stable occupational, religious, and other role systems, and who have satisfactory primary relations, should have a low degree of symbolic commitment. These roles will be their primary concern in their daily lives, and their national role will be latent much of the time. However, they will perceive conformity to national role prescriptions as important for maintaining their identity and/or their status and position in the system. We expect this pattern of normative commitment to characterize the majority of Americans. They are expected to exhibit the following attitudes:

(a) Mild positive affect for national symbols.

(b) Equal or greater emphasis on other roles as compared to the national role.

(c) Tendency to describe the American way of life as their ordinary way of life, and to support policies that preserve and protect it; greater emphasis on aiding and preserving America's way of life than on aiding other countries.

(d) Relatively low level of information, participation, and interest in political affairs.

(e) Passive acceptance of responsibilities of the national role, and expectation that others will so accept them.

\footnotetext{
* The super-patriot movement is also supported by another group of persons who are experiencing status incongruence. Those whose economic power has increased tremendously in recent years but who have little political power, e.g., new millionaires in the Southwest and West, appear to be the principal financial supporters of the movement. Members of the old middle class appear to comprise the active workers.
} 
(f) Tendency to accept any policy that they perceive as generally agreed upon, especially if advocated by national leaders.

We would expect such a commitment to be primarily found in the lower-middle and working classes, among persons who have some functional connection to the system through their occupations and are tied to the community by primary and family relations, but who have no particular responsibility for the maintenance of the system or of major institutions within it. The conformity and indifference characteristic of this type of integration probably depend heavily on the absence of any perceived threat to the individual's established ties. Such a threat would be expected to shift persons so committed to the more intense symbolic involvement.

\section{FUNCTIONAL COMMITMENT}

The functionally committed are those who derive major rewards from their participation in the system; alternatively, these rewards may come from political, religious, or social institutions whose maintenance they view as dependent on the effective functioning of the larger national system. They define their role as nationals in terms of their institutional responsibilities. Such individuals should be characterized by the following attitudes:

(a) Low affect for national symbols.

(b) Definition of the national role in terms of political or social responsibilities.

(c) Relative satisfaction with system rewards and system opportunities.

(d) Relatively high level of information, participation, and interest in political affairs.

(e) Support for policies they view as instrumental to the national interest.

We would expect such a commitment to occur primarily among the upper-middle and upper classes, and among those with considerable education. It should also char- acterize those whose power and status are being enhanced by current patterns of social or political change. It should be especially characteristic of top administrators in bureaucratic organizations.

\section{ALIENATION}

Alienation from the national system, a rejection of the emotional and material benefits derived from participation in it, and a willingness to suffer the consequences of nonconformity to the prescriptions of the national role would be expected where there are few or no direct ties between the individual and the system. Such a condition may be characteristic of members of disadvantaged minorities and deviant subcultures. If active rejection of the national role is to occur among members of such groups, one can expect that there will be alternative value systems to which they can relate themselves.

Messianic religious movements, revolutionary social movements, and even some nativistic groups often offer such altemative values. Thus an important characteristic shared by such diverse groups as Jehovah's Witnesses, the Communist Party in the United States, and the Black Muslims is that they reject the duties of the American national role and the values underlying it. Instead they call for a "higher" loyalty to some system of values that transcends the American state. It is significant to note that these movements appeal to the deprived and poorly integrated segments of the population.

THE RELATIONSHIP OF TYPES OF NATIONAL INVOLVEMENT TO INTERNATIONAL ATTITUDES

We hypothesize that symbolic commitment will be associated with more hostility toward other nations than functional commitment, more perception of hostility on the 
part of other nations toward the individual's own country, less willingness to cooperate with these nations, and less willingness to support attempts at international organization such as the United Nations. The rationale for this hypothesis is that symbolic commitment takes on a life of its own while functional involvement is concerned with individual and group interest. Commitment of a symbolic character is enhanced when national symbols maintain their purity and power in reflecting national identity; it is threatened by competition and conflict with the symbols of outgroups. Functional commitment, on the other hand, is strengthened as the rewards of the system to its members increase.

Since international cooperation can provide increased rewards to the members of a national state, functionally committed persons are more open to it. Under certain conditions, it is true, the functionally involved will push for an aggressive foreign policy if their nation has the power to achieve its goals with little cost by such a policy. Our general assumption, however, is that the risks of war in producing an atomic holocaust and the difficulties of coercion by military means in the modern world are sufficiently great to make the functionally committed more interested in seeking other solutions.

We would predict, moreover, that normatively committed people would fall between the symbolic and the functional groups in their attitudes toward other nations and toward international cooperation. They would tend to follow the positions of national leaders and, for the period during which our interviews were conducted, the national leadership occupied a position somewhere between the functional requirements of the situation and symbolic demands of the people as these leaders perceived them.
Within this basic theoretical framework for analyzing the individual's relationship to his nation-state, a survey was designed to test the predictions presented above.

\section{Methods}

\section{THE INTERVIEW SCHEDULE}

The interview schedule had two parts. ${ }^{5}$ Part I consisted of questions directly related to the respondent's conception of his role as a national. It included questions designed to tap the nature of the respondents' ties with the United States, his conception of what constituted a "good" and a "bad" American, and his general conception of the important things for an individual to learn and know. There was also a series of questions concerning the responsibilities an individual has toward his government, and the areas of life in which the government can legitimately make demands on its citizens. Finally, one group of questions inquired into the respondent's conception of the differences between the US and other countries.

Part II consisted primarily of attitudinal items and demographic questions. Questions were designed to tap attitudes that were expected to be related to the nature of one's ties to his country, including the type of organizations the respondent supported, and his feelings about the assassination of President Kennedy. Perhaps the largest set of attitude questions dealt with foreign affairs, inquiring into attitudes toward Russia, Cuba, the US foreign aid program, the amount of power which should be given to the US military, the efficacy and potential of the United Nations and the World Court, and

5 The questionnaire was primarily the work of Richard Flacks, Herbert Kelman, and Daniel Katz. Flacks also assisted in the development of the coding manual. 
attitudes toward world disarmament. Finally, a series of items was included to obtain standard demographic data, as well as some indication of the nature and intensity of the respondent's ties with other persons and voluntary organizations. ${ }^{8}$

The final schedule contained 252 items. $^{7}$ This schedule required considerable time to administer, with the range running from two to five hours; interview time averaged about three hours.

\section{THE SAMPLE}

A member of the sampling staff of the Survey Research Center at the University of Michigan chose a random sample of 200 households from the city directory for the Greater Ann Arbor Area. He was instructed to exclude anyone whose occupation indicated an obvious affiliation with the University. This was done to ensure that the sample would be representative of nonuniversity-affiliated persons, and to avoid the oversampling of such people, relative to

${ }^{6}$ This schedule was developed out of a pretest questionnaire administered to some 30 residents of the Ann Arbor, Michigan, area. The pretest interviews were used to assess the effectiveness of each item in eliciting relevant information, and to determine areas where interviewing aids and special interviewer training would be needed.

${ }^{7}$ There were 114 open-end items and appropriate probes. There were also 75 forced choice items; in cases where the categories provided were numerous and/or lengthy, the alternatives were presented to the respondent printed on $5^{\prime \prime} \times 8^{\prime \prime}$ index cards. Forty mixed questions were employed, whose wording implied possible responses (e.g., "Have you heard of the Black Muslims?" "Does the military have too much power or not enough?"). Finally, 23 items required the interviewee to rank five or more alternatives in order of preference or importance; in each case, alternatives were presented on a prepared index card. the national population, that would occur in a completely random sample of residents of this area.

Letters were sent to the interviewees explaining that the recipient had been randomly selected to be interviewed, that the study was a legitimate research activity, that their responses would be entirely confidential, and that their cooperation was desired. These letters were sent approximately one week prior to the attempt to make initial contact with the respondent.

Interviewers were instructed to conduct the interviews with the respondent alone if possible; they were successful in almost all cases. Also, each interviewer was instructed to interview only the head of the household or his spouse, and to interview about half males and half females. They followed these directions in both cases; the final sample included 54 percent males and 46 percent females.

Of the 200 initial names, 129 were completely interviewed. 8 Due to limitations of time, and the belief that the 129 interviews obtained were well-done and thus adequate, the 71 uncompleted interviews were not replaced.

${ }^{8}$ In 10 cases, interviewers had to return a second time to complete an interrupted interview. All others were completed in one session. Three interviews were not completed. In one case, the interviewee was called away, and the interviewer was unable to reestablish contact; in the other two, the respondent terminated the interview. Further, 22 persons refused to be interviewed. An additional fifteen persons could not be contacted during the two and one-half month interviewing period. Of the remaining 31 sample addresses, fourteen no longer existed (the sample was taken from the 1962 City Directory; interviews were conducted during April-June of 1964); their nonexistence was verified in most cases by the return of the undelivered contact letter. The other 17 addresses were either vacant at the time of interviewing, or had been converted to businesses. 


\section{THE INTERVIEWERS}

The interviews were conducted by the principal author, and by one paid male and six paid female interviewers. The interviewers were between the ages of 25 and 40 , and had previous experience as interviewers for various research units within the University. The interviewers were given some additional training which focused on the intent of various questions and the circumstances in which probes should be used. Care was taken to sensitize them to questions on which the respondent might have difficulty or be inclined not to answer, and techniques were suggested for avoiding or solving such problems.

Each interviewer completed from five to twenty interviews. With each interview returned, the interviewer included a brief written resume concerning the respondent, an estimate of his seriousness and sincerity in answering the questions, the number of contacts attempted before reaching him, the setting(s) and time(s) of day of the interview, and any unusual difficulties. In all but a few instances, these resumés gave us no reason to doubt the validity of the data.

\section{CODING AND RELIABILITY}

As noted in footnote 7, 23 items required the respondent to rank alternatives and 75 were closed-end items. For these, the appropriate response categories were readily apparent. For some demographic items, excellent codes were adopted from previous Survey Research Center studies (for occupation, religious preference, birthplace, age, and education).

For the remaining items, codes were developed on the basis of both the type of data the item was designed to elicit and the responses made to it. Twenty-five of the interviews (done by different interviewers) were chosen, and a typescript prepared of
TABLE I

Coding Reliability: Number of Items Attaining Grven Levels of AgreEMeNT

\begin{tabular}{|c|c|c|}
\hline $\begin{array}{c}\text { Level of } \\
\text { agreement }\end{array}$ & $\begin{array}{c}\text { First Set: } \\
\text { number of items }\end{array}$ & $\begin{array}{c}\text { Second Set: } \\
\text { number of items }\end{array}$ \\
\hline $100 \%$ & 173 & 209 \\
\hline$\geqslant 90 \%$ & 81 & 64 \\
\hline$\geqslant 80 \%$ & 25 & 25 \\
\hline$\geqslant 70 \%$ & 41 & 17 \\
\hline$\geqslant 60 \%$ & 1 & 6 \\
\hline \multirow[t]{2}{*}{$\geqslant 50 \%$} & 4 & 4 \\
\hline & 325 & 325 \\
\hline \multicolumn{3}{|c|}{ Mean $\%$} \\
\hline
\end{tabular}

the responses elicited by each item. These typescripts were studied, and a code was developed to capture as much relevant information as possible. In several cases, multiple codes were developed for responses to a single question. Finally, 21 indices were constructed, each of which summarized responses to several individual questions or required the coder to make some overall inference from the actual responses themselves. The completed manual contained 325 codes.

One person coded the entire set of 129 interviews. ${ }^{9}$ She was initially trained by the principal author. Special care was taken with those codes or indices which required inferences on her part. Following training, the coder and the senior author independently coded 14 complete interviews. The two judgments were compared for each item on each interview, and all cases of disagreement were discussed and resolved by consensus. From this initial check, a number of ambiguities in the code were discovered and eliminated.

In addition to the 14 interviews which

${ }^{9}$ The authors are sincerely indebted to Michelle Schurgin for three months of hard and sometimes monotonous work on this task. 
TABLE 2

Demographic Characteristics of Sample $(\mathrm{N}=129)$

\begin{tabular}{|c|c|c|c|c|c|}
\hline \multicolumn{3}{|c|}{ RACE } & \multicolumn{3}{|c|}{ SEX } \\
\hline & $\mathbf{N}$ & $\%$ & & $\mathbf{N}$ & $\%$ \\
\hline White & 118 & 91.5 & Male & 70 & 54. \\
\hline Negro & 11 & 8.5 & Female & 59 & 45. \\
\hline
\end{tabular}

\begin{tabular}{lcc}
\multicolumn{3}{c}{ AGE } \\
\hline & $\mathrm{N}$ & $\%$ \\
\hline $21-29$ & 24 & 18.7 \\
$30-39$ & 26 & 20.2 \\
$40-49$ & 28 & 21.7 \\
$50-59$ & 23 & 17.8 \\
$60+$ & 28 & 21.7
\end{tabular}

\begin{tabular}{lrr}
\multicolumn{3}{c}{ EDUCATION } \\
\hline & $\mathrm{N}$ & $\%$ \\
\hline Less than high school graduate & 31 & 24.1 \\
High school graduate & 44 & 34.1 \\
Some college & 19 & 14.7 \\
College graduate & 16 & 12.4 \\
Graduate education & 18 & 14.0 \\
NA & 1 & .7
\end{tabular}

\section{OCCUPATION}

\begin{tabular}{llr}
\hline & $\mathrm{N}$ & $\%$ \\
\hline Farmers & 10 & 7.8 \\
Blue collar workers & 13 & 10.1 \\
White collar workers & 32 & 24.8 \\
Managerial, owners, & & \\
$\quad$ self-employed & 22 & 17.1 \\
Professional-technical & 38 & 29.5 \\
Other & 14 & 10.9
\end{tabular}

RELIGION

\begin{tabular}{lrr}
\hline & $\mathrm{N}$ & \multicolumn{1}{c}{$\%$} \\
\hline Catholic, Orthodox & 18 & 14.0 \\
No preference & 6 & 4.7 \\
Jewish, other non-Christian & 5 & 3.9 \\
Protestant, general & 11 & 8.5 \\
Protestant, Reformation Era $^{\mathrm{x}}$ & 48 & 37.2 \\
Protestant, Pietistic $^{2}$ & 35 & 27.1 \\
Protestant, Neo-Fundamentalist & 3 & 2.3 \\
Non-Traditional Christian & 3 & 2.3
\end{tabular}

ANNUAL INCOME

\begin{tabular}{lrr}
\hline & $\mathrm{N}$ & \multicolumn{1}{c}{$\%$} \\
\hline$<4,000$ & 17 & 13.2 \\
$4,000-5,999$ & 30 & 23.3 \\
$6,000-7,999$ & 23 & 17.8 \\
$8,000-9,999$ & 19 & 14.7 \\
$10,000-14,999$ & 25 & 19.4 \\
$>15,000$ & 11 & 8.5 \\
NA & 4 & 3.1
\end{tabular}

POLITICAL AFFILIATION

\begin{tabular}{lrr}
\hline & $\mathrm{N}$ & $\%$ \\
\hline Republican & $\mathbf{5 8}$ & 45.0 \\
Democrat & 48 & 37.2 \\
Independent & 20 & 15.5 \\
Other & 3 & 2.3 \\
& & \\
& & \\
& &
\end{tabular}

1 Includes Presbyterian, Episcopalian, Lutheran, Congregational and Reform Churches.
2 Includes Methodist, Baptist, Disciples of Christ, and AME Churches.

were independently coded to check the adequacy of the coder's training, 11 interviews which the coder completed in the middle of the series were check-coded. Since the results from both sets are substantially similar, both are presented in Table 1.

For 17 items whose percent agreement was below 70 percent on the second set or below approximately 75 percent on both sets, an additional 25 interviews were checkcoded. For all but one of these items, the percent agreement over these 25 was 75 percent or above.

Thus the data indicate that the code employed with these interviews can be and was used with a fairly high reliability. 


\section{Results}

\section{SAMPLE CHARACTERISTICS}

The major demographic characteristics of the sample are presented in Table 2. As noted earlier, the interview contained a number of questions which dealt with the respondents' feelings concerning the assassination of President Kennedy. Seventeen of these were closed-ended questions with four alternatives each, representing gradations in depth of feeling; these were taken directly from an NORC study done at the time of the assassination, using a national sample of respondents (Sheatsley and Feldman, 1964). A systematic comparison of the percentage of respondents endorsing each alternative in the present study with the percentages obtained by NORC indicates only one difference: a smaller percentage of those in the present study endorsed "Very deepest feeling" on each question. This decrease, which produces a difference larger than 10 percent on only one item, is perhaps consistent with the fact that our interviews were conducted from four to six months after the assassination. The rank-order of percent endorsing each alternative on a given item is the same as that obtained in the NORC study. This similarity to the national sample provides evidence that, at least for these questions, the present sample was representative of the population.

\section{INTEGRATION SCALES}

In order to provide a meaningful analysis of the data from the large variety of questions employed, scales were developed to tap each of the three types of national commitment or involvement.

Prior to any detailed analysis of the data, a number of questions were selected which, on the basis of the conceptual framework, should be related to one of the three types.
Only those response categories for a given item were included which the three authors agreed should indicate one type of involvement. A dichotomous distribution was constructed for each such item with "one" being given the response indicative of symbolic, normative, or functional involvement, and "zero" the response indicating its absence. In some cases, a +2 score was given to a third category which indicated a higher degree of that type of commitment, and/or a -1 and -2 given to categories which indicated the opposite of that type of involvement. The latter was done only on items where response categories were in terms of strength of endorsement.

Some 15 to 20 items thus selected for each type of commitment were intercorrelated using the phi coefficient (Guilford, 1956). From these results, those items were selected for inclusion in the scale which (a) were correlated with at least one other item at the $\mathrm{p}<.05$ level or beyond, or $(\mathrm{b})$ seemed on $a$ priori grounds to be closely related to some aspect of that type of involvement.

The items employed in each of the three scales and the scoring patterns adopted are indicated in Tables 3a, 4a, and 5a. Tables $3 \mathrm{~b}$ and $3 \mathrm{c}$ contain the item intercorrelation and score distribution data respectively for the Symbolic Scale; Table $4 \mathrm{~b}$ and $4 \mathrm{c}$ provide this information for the Normative Scale, and Tables $5 \mathrm{~b}$ and $5 \mathrm{c}$ provide it for the Functional Scale.

Perusal of the items included in each scale should indicate that they follow fairly directly from the conceptual framework. Particularly in the case of the Symbolic and Normative scales, the items included appear to tap the principal components of each type of commitment. Of the item intercorrelations within the Symbolic scale, 13 out of 28 were significant at the $\mathrm{p}<.05$ level or above. In the Normative scale, a smaller 
TABLE 3a

Symbolic Commitament Scale: Iteass and Response Distrubuttons

\begin{tabular}{lll}
\hline & \multicolumn{2}{l}{ Distribution } \\
\cline { 2 - 2 } Questions and Codes & $\mathrm{N} \%$ & Scoring \\
\hline
\end{tabular}

Item 1: "Suppose a person criticizes the government in time of national crisis. In your opinion, could he be a good American?"

Could be; Yes

Depends: on kind of criticism, nature of crisis

No, unqualified

$82 \quad 63.6 \quad 0$

$23 \quad 17.8 \quad 0$

$21 \quad 16.3 \quad 1$

Item 2: "Suppose a person doesn't stand when the Star Spangled Banner is being played. Do you think he could be a good American?"

Yes, unqualified

Yes, if he had a reason-physical, religious

No, qualified

No, unqualified

$\begin{array}{rrr}42 & 32.6 & -1 \\ 43 & 33.3 & 0 \\ 6 & 4.7 & 1 \\ 31 & 24.0 & 2\end{array}$

Item 3: "Do you happen to own a flag?"

Yes

No

$\begin{array}{lll}70 & 54.3 & 1\end{array}$

Other; once did, NA

$39.5 \quad 0$

(For those who own flag) "Do you ever

$51 \quad 39.5$

$8 \quad 6.2$

display it on national holidays?"

Always; yes

Usually; sometimes

Never; no

Other; inappropriate

$\begin{array}{rrr}34 & 26.4 & 1 \\ 11 & 8.6 & 1 \\ 23 & 17.8 & 0 \\ 61 & 47.2 & 0\end{array}$

Item 4: "Some observers have complained that the American public nowadays does not pay proper respect to the American flag. Would you agree or disagree with this compaint?"

Agree

Disagreee

Other

Item 5: "What would you think of an American who says that he takes no particular pride in our armed forces?"

Approve; he has a right to say that

Indifferent; nothing; don't know

Disapprove, general

Disapprove: not a good American

Other

Item 6: "Imagine the American Peace Corps comes up in a conversation between yourself and a foreigner and he laughs at it. How do you think you would react when this occurswould you regard this as an insult, or a sign of poor taste, or a personal opinion to which he is entitled?" 
TABLE 3a (Continued)

\begin{tabular}{cccc}
\hline & \multicolumn{3}{c}{ Distribution } \\
\cline { 2 - 3 } Questions and Codes & $\mathrm{N}$ & $\%$ & \multicolumn{1}{c}{ Scoring } \\
\hline An insult & 13 & 10.1 & 1 \\
A sign of poor taste & 21 & 16.3 & 0 \\
An opinion to which he is entitled & 79 & 61.2 & 0
\end{tabular}

Item 7a: "How would you feel if a foreigner criticized racial segregation in the US?"

7b: "How would you feel if a foreigner attacked the free enterprise system?"

An insult; poor taste; would be mad

He is wrong; would argue with him

Depends: where he's from, what he says

An opinion to which he's entitled

Would like to talk to him

$\mathrm{He}$ is right; would agree with him

Other

\begin{tabular}{rr}
\multicolumn{2}{c}{ Item 7a } \\
\hline $\mathrm{N}$ & \multicolumn{1}{c}{$\%$} \\
\hline 22 & 17.1 \\
7 & 5.4 \\
10 & 7.8 \\
40 & 31.0 \\
2 & 1.6 \\
34 & 26.4 \\
14 & 10.9
\end{tabular}

\begin{tabular}{rrrr}
\multicolumn{2}{c}{ Item $7 \mathbf{b}$} & & \\
\cline { 1 - 2 } \cline { 1 - 1 } $\mathbf{N}$ & \multicolumn{1}{c}{$\%$} & Scoring \\
\cline { 1 - 2 } 38 & 29.5 & & $1^{* *}$ \\
32 & 24.8 & & 0 \\
2 & 1.6 & & 0 \\
26 & 20.2 & & 0 \\
9 & 7.0 & & 0 \\
4 & 3.1 & & 0 \\
18 & 13.9 & & 0
\end{tabular}

Item 8: "How do you feel about the following quotation: Do you strongly agree, slightly agree, slightly disagree, or strongly disagree? 'Whereas some people feel that they are citizens of the world, that they belong to mankind and not to any one nation, I, for my part, feel that I am first, last, and always an American."

Strongly agree

Slightly agree

$\begin{array}{rrr}76 & 58.9 & 1 \\ 28 & 21.7 & 0 \\ 11 & 8.5 & -1 \\ 10 & 7.8 & -2\end{array}$

Slightly disagree

Strongly disagree

** One point only if coded in this category on both items.

TABLE $3 b$

Symbolic Commitment Scale: Item Interrelations; Phi Coefricient

\begin{tabular}{|c|c|c|c|c|c|c|c|c|}
\hline & 1 & 2 & 3 & 4 & 5 & 6 & 7 & 8 \\
\hline 1 & 一 & $.20^{\mathrm{a}}$ & .06 & .00 & $.18^{\mathrm{a}}$ & .13 & $.32^{c}$ & .15 \\
\hline 2 & & - & .06 & $.21^{\mathrm{b}}$ & $.19^{a}$ & .06 & $.26^{\mathrm{c}}$ & $.25^{\mathrm{c}}$ \\
\hline 3 & & & - & $.31^{\mathrm{c}}$ & $.21^{\mathrm{b}}$ & .00 & .00 & .12 \\
\hline 4 & & & & - & $.28^{\circ}$ & .00 & .00 & $.24^{\mathrm{e}}$ \\
\hline 5 & & & & & 一 & $.24^{\mathrm{o}}$ & .15 & $.28^{\mathrm{c}}$ \\
\hline 6 & & & & & & - & $.38^{\mathrm{c}}$ & .08 \\
\hline 7 & & & & & & & - & .09 \\
\hline 8 & & & & & & & & - \\
\hline
\end{tabular}

TABLE 3c

Symbolic Compmrtment Scale: Scale Score Distribution

\begin{tabular}{|c|c|c|c|}
\hline Score & $f$ & $\%$ & Label \\
\hline 5 to 8 & 36 & 27.9 & High \\
\hline 3 and 4 & 36 & 27.9 & High-Medium \\
\hline 1 and 2 & 29 & 22.5 & Low-Medium \\
\hline \multirow[t]{2}{*}{-4 to 0} & 28 & 21.7 & Low \\
\hline & 129 & 100.0 & \\
\hline
\end{tabular}


TABLE 4a

Normative Commitment Scale: Items and Response Distributions

\begin{tabular}{lll}
\hline & Distribution \\
\cline { 2 - 3 } Questions and Codes & $\mathrm{N}$ Scoring \\
\hline
\end{tabular}

Item 1: "What do you think a person ought to do in order to be a good American?"

Mentioned formal requirements: vote, pay taxes, serve in Army, support constitution.

Did not mention the above

45

84

34.9

65.1

1

Item 2: "What do you think a person ought to do in order to be a good American?"

Mentioned conformity to norms: obey laws, be honest, stay out of trouble, do the right things, be loyal, live properly, live a clean life, etc.

Did not mention the above

48

81

37.2

62.8

1

Item 3: "Some people say that a person should go along with whatever his country does even if he disagrees with it. How do you feel about that?"

Agree, unqualified; he should

He should go along with majority

Has no choice, has to go along

Depends: on the issue, the person

Disagree: he has a right to criticize

Disagree: government could be wrong

Item 4: "Suppose a law was passed raising income taxes by fifty percent. Would you pay the tax without question, refuse to pay if a good many other people refused, or refuse regardless of what others did?"

Pay without question

Refuse if others did

Refuse regardless

Item 5: "Suppose a law was passed requiring all citizens to be fingerprinted and to carry identity cards. Would you obey without question, not obey if a good many others also refused to obey, or not obey regardless of what others did?"

Obey without question

Refuse if others did

Refuse regardless

Items 6-8: "Here is a list of things that a government might ask its citizens to do.

a. First, go through this list and tell me which things the government should require people to do.

b. Now go through the list and tell me which of these things you think the government should encourage people to do, but which they have a right to refuse if they prefer. 
TABLE $4 \mathrm{a}$ (Continued)

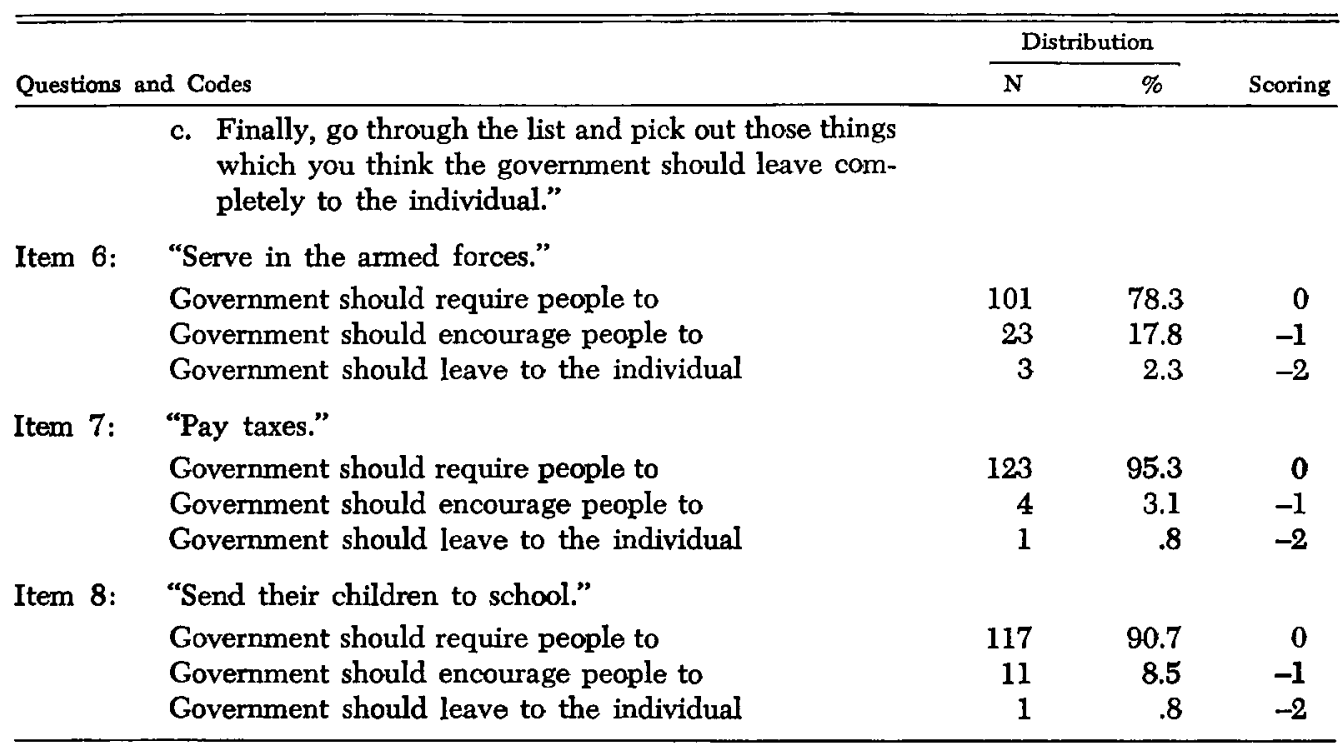

TABLE $4 b$

Normative Commitment Scale: Item Interrelations; Phi Coefficient

\begin{tabular}{|c|c|c|c|c|c|c|c|c|}
\hline & 1 & 2 & 3 & 4 & 5 & 6 & 7 & 8 \\
\hline 1 & - & .00 & .044 & .125 & $.20^{\circ}$ & .038 & .00 & .122 \\
\hline 2 & & - & -.059 & $.194^{\mathrm{a}}$ & $.22^{\mathrm{b}}$ & .147 & .00 & .00 \\
\hline 3 & & & - & .125 & .115 & $.246^{\mathrm{c}}$ & .148 & .045 \\
\hline 4 & & & & - & $.29^{\mathrm{c}}$ & .133 & $.178^{\mathrm{a}}$ & .00 \\
\hline 5 & & & & & - & $.183^{\mathrm{a}}$ & .00 & .00 \\
\hline 6 & & & & & & - & .10 & .038 \\
\hline 7 & & & & & & & - & $.212^{\mathrm{b}}$ \\
\hline 8 & & & & & & & & - \\
\hline
\end{tabular}

number of phi coefficients were significant.

The Functional Commitment Scale was less satisfactory. Here, some of the items originally designed to tap this type of involvement did not elicit responses which could be employed as scale items. What remains are six items; three of these are economic in nature, and the scale is thus biased in this respect. Also, these six show a gen-
TABLE $4 \mathrm{c}$

Normattve Commrtment Scale: Scale Score Distrubution

\begin{tabular}{cccl}
\hline \hline Score & $f$ & $\%$ & Label \\
\hline 4 and 5 & 24 & 18.6 & High \\
3 & 30 & 23.3 & High-Medium \\
2 and 1 & 49 & 38.0 & Low-Medium \\
-4 to 0 & $\frac{26}{20.1}$ & Low \\
\cline { 2 - 4 } & $\frac{20.0}{129}$ & & \\
\hline
\end{tabular}

erally nonsignificant pattern of relations with one another.

Correlations between scores on each pair of scales were computed. For this purpose, the Pearson product-moment coefficient was judged most appropriate, even though these score distributions are not completely normal. The resulting correlations are presented in Table 6. The coefficients indicate that the Symbolic and Normative scales are not entirely independent, though the overlap in terms of variance is quite small (less than 4 percent). 
TABLE 5a

Functional Commttment Scale: Items and Response Distributions

\begin{tabular}{llll}
\hline & \multicolumn{2}{l}{ Distribution } & \\
\cline { 2 - 4 } & $\mathrm{N}$ & $\%$ & Scoring \\
\hline
\end{tabular}

Item 1: "What are some of the things that particularly remind you that you are an American?"

Mentioned opportunity: affluence, standard of living, free enterprise; accomplishment, progress.

Did not mention the above

$\begin{array}{lll}37 & 28.7 & 1 \\ 91 & 70.5 & 0\end{array}$

Item 2: "What do you think a person ought to do in order to be a good American?"

Mentioned participation: be informed, participate in public affairs, use citizenship rights; take part in community, vote intelligently, etc.

Did not mention the above

$55 \quad 42.6 \quad 1$

$74 \quad 57.4 \quad 0$

Item 3: "Are there any people you know or have heard about who you think are not good Americans?"

Mentioned apathetic persons: people who don't appreciate what they have, our opportunities; people who don't accept their responsibilities as citizens.

Did not mention the above

$\begin{array}{rrr}8 & 6.2 & 1 \\ 121 & 93.8 & 0\end{array}$

Item 4: "What do you think people mean when they talk about the American way of life?"

Mentioned affluence: high standard of living, free enterprise, freedom (defined in terms of consumption), security, happiness.

Did not mention the above

$55 \quad 42.6 \quad 1$

Item 5: "What do you think are the the most important things that make America different from other countries?"

Mentioned opportunity: advancement, chance to get ahead.

Did not mention the above

$\begin{array}{lll}19 & 14.7 & 1\end{array}$

Item 6: "What do you think are the most important things that make America different from other countries?"

Mentioned affluence: high standard of living, ease of living, convenience; modern civilization; industrialization;

free enterprise.

$\begin{array}{lll}40 & 31.0 & 1\end{array}$

Did not mention the above

$87 \quad 67.4 \quad 0$

\section{DATA ANALYSIS}

The small number of persons with a given scale score value and the tentative nature of the scales themselves led to a decision to analyze the data in terms of score groups on each scale rather than in terms of exact score values. For these purposes, the dis- tribution on each scale was divided into four groups; cut-off lines were chosen to obtain groups of roughly equal size which would also be meaningful. These four groups are designated: High (H), High-Medium (HM), Low-Medium (LM), and Low (L), and their composition is indicated on the scale score 
TABLE $5 \mathrm{~b}$

Functional Commttment Scale: Item Interrelations; Phi Coefficient

\begin{tabular}{|c|c|c|c|c|c|c|}
\hline & 1 & 2 & 3 & 4 & 5 & 6 \\
\hline 1 & - & .043 & $.192^{\mathrm{a}}$ & .147 & .00 & .057 \\
\hline 2 & & - & .103 & .049 & .172 & .066 \\
\hline 3 & & & - & .103 & .00 & -.105 \\
\hline 4 & & & & - & .00 & $.235^{b}$ \\
\hline 5 & & & & & - & .137 \\
\hline 6 & & & & & & - \\
\hline
\end{tabular}

distribution tables, $3 c, 4 c$, and $5 c$. Note that the entire sample appears in each of these distributions. It is not necessarily true that the Low group on a given scale represents the complete absence of that type of commitment; high, medium, and low are labels that refer only to relative standing on these scales.

\section{PURE GROUPS ANALYSIS}

In order to obtain meaningful comparisons between scale groups, the data were analyzed by dividing the respondents into what are termed "pure groups." In this analysis each person appears in a given comparison only once, on the basis of his standing on all three scales.

These "pure groups" were constructed as follows: each person who was in the High

TABLE 5c

Functional Commitment Scale: Scale SCORE Distributton

\begin{tabular}{cccl}
\hline Score & f & $\%$ & Label \\
\hline 3 to 5 & 33 & 25.5 & High \\
2 & 29 & 22.5 & High-Medium \\
1 & 45 & 35.0 & Low-Medium \\
0 & 22 & 17.0 & Low \\
\cline { 2 - 3 } & $\frac{129}{129}$ & 100.0 & \\
\hline
\end{tabular}

TABLE 6

Correlations Between Scales

\begin{tabular}{lcc}
\hline \hline & Normative & Functional \\
\hline Symbolic & $.1876^{*}$ & -.1077 \\
Normative & - & -.105 \\
\hline$* \mathrm{p}<.025$ & &
\end{tabular}

or HM group on one of the three individual scales, and in the LM or Low group on the other two scales, was classed as representing the type of involvement tapped by the first scale. Thus, the 22 respondents who were in the High or HM groups on the Symbolic scale and in the LM or Low groups on the Normative and Functional scales comprise the Symbolic (Sym) group. Similarly, there were ten in the Normative (Norm) group and 19 in the Functional (Func) group. Also, those who were in the High or HM group on all three scales were grouped together ( $\mathrm{HHH} ; \mathrm{N}=21$ ), and those who were in the LM or Low group on all three were grouped (LLL; $N=20$ ). The remaining 37 respondents, who were in the High or HM groups on two of the three scales, were lumped as "Other."

The responses of each of these groups were then tabulated for every item in the interview schedule, and the major results of this analysis are presented below. Here, we are concerned with differences in endorsement rates as a function of group membership. That is, only the data for those items in which two of the six pure groups differed by at least 25 percent in endorsement rate are included. This criterion is based on the estimate that differences should be at least this large, given the small $\mathrm{N}$ in each group, before they become meaningful. What is important in this analysis is the overall pattern which emerges from those items which show differences, and its consistency; differences on individual items are not of basic importance. 
Each of the items on which differences in response were found was placed in one of the following nine categories:

Demographic characteristics;

Strength of commitment to the country;

Perception of the national role;

Perception of unique characteristics of America;

Reactions to the assassination of President Kennedy;

Attitudes toward US defense policies and disarmament;

Attitudes toward foreign relations;

Attitudes toward supranational organizations; and

Indications of passive alienation.

With the exception of demographic characteristics, we conceive these as outcomes of the type of commitment (especially the last five groups). These categories will be considered in the order in which they are listed above.

\section{DEMOGRAPHIC ITEMS}

The demographic items on which variation was found across groups are shown in Table 7. Members of the Normative group were more likely to be male, while members of the Functional group were more likely to be female; the ratio was about $50-50$ in the other groups. Age variation was quite apparent; those in the Symbolic and Normative groups were much more likely to be over 40 (as were the members of the $\mathrm{HHH}$ and Other groups), while members of the Functional group were most frequently under 40. Educational differences were also found; virtually no one in the Symbolic group had attended college, while almost everyone in the Functional group had. Occupationally, members of the Functional group were slightly more frequently classed as "professional-technical," while only one member of the Symbolic group was in this category; these relations are reversed in the "craftsmen, foremen, and kindred workers" category. Those in the Normative group were more likely to be in jobs classed as "operative and kindred workers." Also, a much higher proportion of those in the Functional group than in either the Symbolic or Normative reported incomes of $\$ 8,000$ or more. The education, income, and occupation data are related, as is generally the case; thus Functionals tended to be better educated, have higher status jobs, and have a higher income.

One item asked the respondent whether he belonged to the "lower class," "working class," "middle class," or "upper class." On this "perceived status" item, those in the Functional group were much less likely to indicate that they belonged to the "working class," much more frequently report they were members of the "middle class." The remaining groups were about equally likely to pick either. When asked what the major differences are between the two classes, "None" was the most frequent response of the Symbolic group, least often given by members of the Functional one. Conversely, the Functional was the only group to respond with any frequency that education or cultural factors are the primary difference.

The Symbolic group is distinguished from the other five groups by the greater preference of its members for religions classed as "pietistic Protestant." On the other hand, members of the Functional group (and the $\mathrm{HHH}$ ) are more likely to attend church weekly. Politically, the Normative group less frequently indicated a preference for the Republican party; its members were also least likely to have voted in the 1960 presidential and 1962 gubernatorial elections, or to have voted Republican in both elections (according to their reports). (The HHH and Other groups have the highest proportion of members for whom these statements are 
TABLE 7

DEMOGRAPHIC ITEMS

\begin{tabular}{|c|c|c|c|c|c|c|c|}
\hline \multirow[t]{2}{*}{ Demographic Characteristic } & & \multicolumn{6}{|c|}{ Percent endorsement } \\
\hline & & SYM & NORM & FUNC & LLL & HHH & OTHER \\
\hline & $(\mathrm{N}=)$ & $(22)$ & $(10)$ & (19) & (20) & (2I) & $(37)$ \\
\hline Sex: Male & & 50.0 & 70.0 & 36.8 & 55.0 & 52.4 & 62.2 \\
\hline Age: 40 or older & & 59.1 & 60.0 & 31.5 & 20.0 & 57.2 & 62.1 \\
\hline Education: 13 years or more & & 9.0 & 40.0 & 84.0 & 50.0 & 38.0 & 35.1 \\
\hline Graduate training & & 0.0 & 20.0 & 42.1 & 30.0 & 0.0 & 5.4 \\
\hline \multicolumn{8}{|l|}{ Occupation: } \\
\hline Professional and technical & & 4.5 & 20.0 & 31.6 & 30.0 & 19.0 & 21.6 \\
\hline Craftsmen, foremen, kindred & & 22.7 & 10.0 & 0.0 & 5.0 & 9.5 & 27.0 \\
\hline Operatives and kindred & & 13.6 & 30.0 & 5.3 & 0.0 & 4.8 & 8.1 \\
\hline Income: $\$ 8,000$ per year or more & & 18.1 & 30.0 & 52.7 & 35.0 & 61.9 & 48.6 \\
\hline \multicolumn{8}{|l|}{ Perceived status: } \\
\hline "Working class" & & 36.4 & 40.0 & 10.5 & 25.0 & 47.6 & 32.4 \\
\hline "Middle class" & & 45.5 & 50.0 & 89.5 & 50.0 & 42.9 & 67.6 \\
\hline \multicolumn{8}{|l|}{$\begin{array}{l}\text { Differences between "middle" } \\
\text { and "working" class: }\end{array}$} \\
\hline None & & 54.5 & 30.0 & 0.0 & 25.0 & 33.3 & 27.0 \\
\hline Education, cultural level & & 0.0 & 0.0 & 36.8 & 5.0 & 9.5 & 8.1 \\
\hline \multicolumn{8}{|l|}{ Religious preference: } \\
\hline Pietistic Protestant ${ }^{1}$ & & 45.5 & 20.0 & 21.1 & 20.0 & 23.8 & 27.0 \\
\hline Attends religious services: & & & & & & & \\
\hline once per week & & 22.7 & 10.0 & 47.4 & 30.0 & 47.6 & 27.0 \\
\hline \multicolumn{8}{|l|}{ Political preference: } \\
\hline Republican & & 40.9 & 20.0 & 36.8 & 40.0 & 57.1 & 54.1 \\
\hline \multicolumn{8}{|l|}{ Political behavior: } \\
\hline Voted in both 1960 and 1962 & & 72.7 & $\mathbf{4 0 . 0}$ & 52.6 & 60.0 & 85.7 & 83.8 \\
\hline Voted Republican in both & & 31.8 & 10.0 & 26.3 & 25.0 & 57.1 & 64.9 \\
\hline \multicolumn{8}{|l|}{ Father's education: } \\
\hline 13 years or more & & 13.6 & 30.0 & 47.4 & 35.0 & 0.0 & 13.5 \\
\hline \multicolumn{8}{|l|}{ Father's occupation: } \\
\hline Professional and technical & & 4.5 & 20.0 & 31.6 & 25.0 & 4.8 & 10.8 \\
\hline Craftsmen, foreman, kindred & & 22.7 & 40.0 & 15.8 & 15.0 & 4.8 & 27.0 \\
\hline Farmer & & 45.5 & 30.0 & 10.5 & 10.0 & 42.9 & 21.6 \\
\hline \multicolumn{8}{|l|}{ Stability: } \\
\hline \multicolumn{8}{|l|}{ Lived in Ann Arbor area } \\
\hline 10 years or more & & 91.0 & 40.0 & 31.6 & 70.0 & 90.4 & 67.5 \\
\hline \multicolumn{8}{|l|}{ Moved 3 or more times in past } \\
\hline 10 years & & 9.1 & 20.0 & 47.4 & 45.0 & 9.6 & 29.7 \\
\hline Married for 10 years or more & & 59.1 & 70.0 & 36.9 & 35.0 & 66.7 & 59.4 \\
\hline \multicolumn{8}{|l|}{ Rural vs. urban background } \\
\hline Brought up mostly on a farm & & 54.5 & 40.0 & 21.1 & 15.0 & 33.3 & 29.7 \\
\hline Lived on a farm 10 years or more & & 58.1 & 60.0 & 10.6 & 15.0 & 32.3 & 35.1 \\
\hline
\end{tabular}


TABLE 7 (Continued)

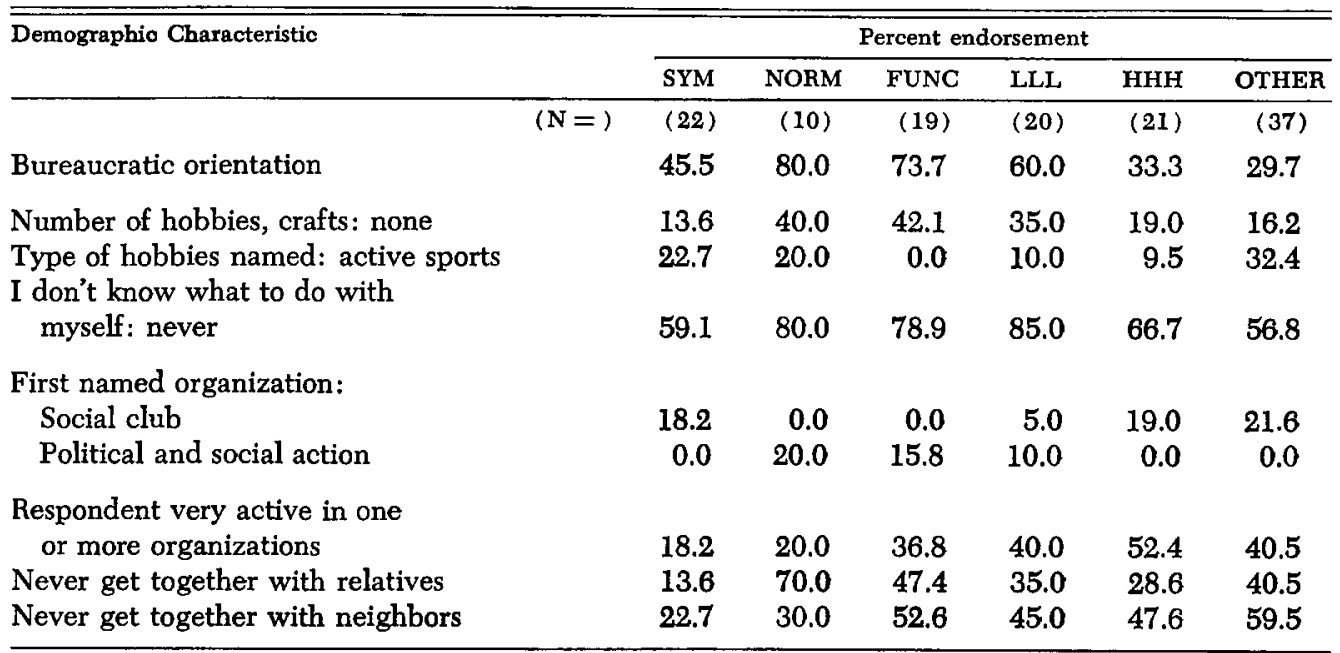

1 See Table 2 for a list of the religions comprising this category.

true.) The Symbolic group's members were more likely to have voted in 1960 and 1962 than members of the Normative and Functional groups.

As was true of the respondents themselves, the fathers of those in the Functional group much more often had some college education. The members of this group were also more likely to have a father whose occupation was a "professional-technical" one while they were growing up. Those in the Normative group were most likely to have grown up while the father was a craftsman or foreman. Members of the Symbolic group had most often grown up in farming families, and those in the Functional group were least likely to have done so.

Three items showing relations with score group may be interpreted as indices of stability. Almost everyone in the Symbolic group has lived in this area for at least 10 years, while those in the Normative and Functional groups were the least likely to have done so. On an item dealing with number of moves, those in the Functional (and LLL) group were most likely to have moved at least three times in the past 10 years, and those in the Symbolic (and HHH) were least likely to have moved this often. Finally, the Normative and Symbolic group members were somewhat more likely than those in other groups to have been married for at least 10 years.

A pair of items provides an indication of rural-urban background differences between the various score groups. The Symbolic and Normative groups' members were more likely than those in the remaining groups to have been raised on a farm and/or lived on one for at least 10 years. Respondents in the Functional group were least likely to have such a rural background.

The next item shown in Table 7 provides an index of entrepreneurial as against bureaucratic orientation. This question asked whether pressing national problems should be met by large government and private organizations, by large private organizations, or by the strengthening of individual freedom and responsibility. Endorsement of the first alternative is taken as an indication of a 
bureaucratic orientation on the part of the respondent. It can be seen that those in the Normative and Functional groups most frequently favored meeting national problems with large organizations.

Finally, a series of items at the end of the interview dealt with various types of activities in which respondents might participate. First, each interviewee was asked what hobbies, sports, or crafts he engaged in, if any. Looking at simply the number mentioned, those in the Symbolic group were least likely to mention none; those in the Normative and Functional groups did so most frequently. On an index of the predominant nature of these activities, based on the coder's judgment, no one in the Functional group gave active sports as his primary interest, while those in the Symbolic and Normative groups were more likely to do so. Another item asked how often the respondent would say he just did not know what to do with himself; the members of the Symbolic group were least likely to respond "Never."

The respondent was also asked to name all those organizations of which he was a member. Although there were no striking differences in the number named, it is interesting to note that no one in either the Normative or Functional groups named an organization coded as social club first. On the other hand, members of the latter two groups were most likely (and, with two people in the LLL groups, the only ones) to name a "political or social action" organization. The coder, on the basis of all of the respondent's comments about his organizational participation, judged him as "Very," "Fairly," "Somewhat," "Slightly" or "Not" active in organizations. On this index, those in the Normative and Symbolic groups were least frequently "Very active." Finally, those in the Symbolic group were least likely to indicate that they never get together with relatives, those in the Normative group most likely to so state. The members of the Symbolic and Normative groups were least likely to say they never see their neighbors socially.

In sum, those in the Functional group were more likely to be female and younger. In contrast to the Symbolic group, they were most likely to have some college education and graduate training, to have professional or highly skilled occupations, and to earn more than $\$ 8,000$ per year. Those in the Normative group lie between the Functional and the Symbolic on these dimensions. Members of the Symbolic group were more likely to have voted in both 1960 and 1962, and to have voted Republican; those in the Normative group were least likely to have done either.

Respondents in the Functional group least frequently came from a rural background, more often came from a family with an educated, professional father, were the most likely to have come to this area in the past 10 years, and tended to be more geographically mobile. Again, the Symbolic group's members show the reverse of these frequencies. Finally, those in the Symbolic group were most likely to have hobbies and to get together with relatives and neighbors, while those in the Functional group more often appeared to be active in secondary associations and only rarely felt that they had nothing to do.

\section{STRENGTH OF COMMITMENT TO COUNTRY}

A series of items can be interpreted as indicating the respondent's strength of commitment to the country, in the sense that they indicate the value he places on being an American and living within the boundaries of the United States. The data for these items are presented in Table 8.

One of these items presented seven "things that a young man may need to learn in life": knowing how to do his job well, being a 
TABLE 8

Strength of Commitment to Country

\begin{tabular}{|c|c|c|c|c|c|c|}
\hline \multirow[t]{2}{*}{ Response } & \multicolumn{6}{|c|}{ Percent endorsement } \\
\hline & SYM & NORM & FUNC & LLL & HHH & OTHER \\
\hline \multicolumn{7}{|l|}{$\begin{array}{l}\text { Most important thing a young man } \\
\text { needs to learn: }\end{array}$} \\
\hline To be a good American & 31.8 & 20.0 & 10.5 & 10.0 & 33.3 & 27.0 \\
\hline To help his fellow man & 9.1 & 10.0 & 36.8 & 15.0 & 9.5 & 8.1 \\
\hline \multicolumn{7}{|l|}{$\begin{array}{l}\text { Teaching children to appreciate } \\
\text { different ways of life is more } \\
\text { important than to appreciate the }\end{array}$} \\
\hline American way of life & 54.5 & 70.0 & 89.5 & 70.0 & 42.9 & 45.9 \\
\hline $\begin{array}{l}\text { The worst fate a man could suffer: } \\
\text { being exiled from his country }\end{array}$ & 36.4 & 20.0 & 10.5 & 15.0 & 38.1 & 32.4 \\
\hline \multicolumn{7}{|l|}{ Resistance to leaving the US: } \\
\hline $\begin{array}{l}\text { Would consider moving to } \\
\text { another country to live }\end{array}$ & 9.1 & 30.0 & 52.6 & 60.0 & 19.0 & 24.3 \\
\hline Would you consider moving in & 63.6 & 70.0 & 26.3 & 25.0 & 52.4 & 59.5 \\
\hline $\begin{array}{l}\text { a nuclear war and you could save } \\
\text { your family by moving: would move }\end{array}$ & 45.5 & 70.0 & 52.6 & 25.0 & 38.1 & 32.4 \\
\hline $\begin{array}{l}\text { What would you do if a dictatorship } \\
\text { developed in the US? Nothing }\end{array}$ & 31.8 & 30.0 & 5.3 & 15.0 & 14.3 & 13.5 \\
\hline $\begin{array}{l}\text { General: It is a good idea for } \\
\text { more Americans to go to other } \\
\text { countries to live }\end{array}$ & 50.0 & 60.0 & 68.4 & 45.0 & 42.9 & 59.5 \\
\hline $\begin{array}{l}\text { Doing away with national boundaries } \\
\text { is a good idea }\end{array}$ & 18.2 & 40.0 & 52.6 & 20.0 & 4.8 & 29.7 \\
\hline $\begin{array}{l}\text { A person who goes to live in Russia } \\
\text { should be allowed to keep his } \\
\text { citizenship }\end{array}$ & 0.0 & 40.0 & 57.9 & 45.0 & 14.3 & 32.4 \\
\hline
\end{tabular}

good family man, being a good American, making a good income, being a good friend, practicing his religion faithfully, and helping his fellow man, in that order. These were listed on a card given to the interviewee, and he was asked "Which one of these would be most important?" Members of the Symbolic group (and of the HHH group) were most likely to indicate that "being a good American" is of greatest importance for a child to learn. Those in the
Functional group, on the other hand, much more frequently than any other group ranked "helping his fellow man" as of primary importance; in fact, these people were least likely to select being a good American. This is borne out on an item which asked whether appreciation of "the American way of life" or of "different ways of life" is of most importance; the Symbolic group was less likely to select the latter, those in the Functional group most likely to do so. Also, 
members of the Symbolic group were most likely, the Functional least likely, to select exile from the country as the worst fate a man could suffer. (The five alternatives presented were: being poor and hungry, being without friends, being without family, being exiled from his country, and being without religion, in that order.)

A series of items dealt with the conditions under which the respondent would move from the US. The Symbolic group was the most resistant to leaving; its members were by far the least likely to indicate that they would consider moving, more likely to refuse to consider moving for a better job (though they so stated about as often as those in three other groups), and only moderately likely to move under threat of war. They most frequently stated that nothing could be done if a dictatorship developed here. Those in the Functional group were among the least likely to be resistant to moving as measured by these items, with the exception that they less often would consider moving under impending nuclear war than those in the Normative group.

On a general item which asked whether it is "a good idea or a bad idea" for Americans to live in other countries, members of the Functional group more often endorsed it as a good idea; they were also much more likely to believe that "doing away with national boundaries" is a good idea, with those in the Symbolic and $\mathrm{HHH}$ groups least likely to believe so. Again, on an item asking whether a citizen who goes to live in Russia should be allowed to keep his citizenship, no one in the Symbolic group felt that he should be allowed to do so, while those in the Functional group most frequently stated that he should.

\section{NATIONAL ROLE}

Having looked at the strength of commitment of the respondents, let us turn to a consideration of the content of the national role as they perceived it. Table $9 a$ shows the results of those items related to the nature of the role on which differences were found as a function of score group on the scales.

When asked what things reminded them that they were Americans, those in the Normative group were somewhat more likely spontaneously to mention America's freedom or democratic way of life; it is particularly interesting that those in the LLL group were least likely to so respond, those in the $\mathrm{HHH}$ group most likely to do so.

The next question, also open-ended, asked the respondent "What do you think a person ought to do in order to be a good American?" "Interpersonal morality" (e.g., getting along with others, following the Golden Rule) was more often mentioned spontaneously by those in the Normative group. The centering of this group's orientation on general norms is also clearly demonstrated by their more frequently giving responses in the category "violators of laws and/or general norms" when asked who they thought were not "good Americans." These two responses validate the Normative scale to some extent. While those in the Functional group were highly unlikely to mention such violators in response to this question, they mentioned right-wing extremists more often than the other five score groups. Also, note the parallel between the Symbolic and the $\mathrm{HHH}$ groups' responses to this question.

The next part of the interview schedule consisted of a series of items, each of which asked whether a person could be a good American if he was engaged in a certain activity, believed or did not believe in some value or creed, or behaved in a certain way. These were designed to provide more explicit information on the defining criteria of an American. Members of the Functional 
TABLE 9a

Perception of National Role

\begin{tabular}{|c|c|c|c|c|c|c|}
\hline \multirow[t]{2}{*}{ Response } & \multicolumn{6}{|c|}{ Peroent endorsement } \\
\hline & SYM & NORM & FUNC & LLL & HHH & OTHER \\
\hline $\begin{array}{l}\text { Things which remind you that you are an } \\
\text { American: freedom, democracy }\end{array}$ & 45.5 & 60.0 & 47.4 & 30.0 & 71.4 & 64.9 \\
\hline $\begin{array}{l}\text { What a person ought to do to be a good } \\
\text { American: interpersonal morality }\end{array}$ & 27.3 & 50.0 & 21.1 & 40.0 & 9.5 & 21.6 \\
\hline $\begin{array}{l}\text { People who aren't good Americans: } \\
\text { 1. Violators of law or norms } \\
\text { 2. Right-wing extremists, } \\
\text { segregationists }\end{array}$ & 13.6 & 30.0 & 42.1 & 25.0 & 9.5 & 24.3 \\
\hline $\begin{array}{l}\text { A person who does not know the main } \\
\text { principles of the Constitution could } \\
\text { be a good American: unqualified yes } \\
\text { A person who had once been a member } \\
\text { of the Communist party could be a }\end{array}$ & 18.2 & 50.0 & 26.3 & 50.0 & 23.8 & 18.9 \\
\hline $\begin{array}{l}\text { good American: unqualified yes } \\
\text { A person who believes in socialism could }\end{array}$ & 9.1 & 40.0 & 52.6 & 45.0 & 4.8 & 27.0 \\
\hline $\begin{array}{l}\text { be a good American: unqualified yes } \\
\text { A person who preferred jail to serving } \\
\text { in the US Army could be a good }\end{array}$ & 13.6 & 20.0 & 52.6 & 40.0 & 9.5 & 21.6 \\
\hline $\begin{array}{l}\text { American: unqualified no } \\
\text { A person who does not believe in } \\
\text { God could be a good American: } \\
\text { unqualified yes }\end{array}$ & 50.0 & 40.0 & 15.8 & 25.0 & 57.2 & 43.2 \\
\hline $\begin{array}{l}\text { A person who believes in racial } \\
\text { segregation could be a good }\end{array}$ & 00.0 & 10.0 & 10.0 & 00.0 & 02.4 & 01.9 \\
\hline $\begin{array}{l}\text { American: unqualified yes } \\
\text { Indicated that on four or more out } \\
\text { of ten criteria a person could not } \\
\text { be a good American }\end{array}$ & 31.8 & 70.0 & 10.5 & 35.0 & 43.0 & 32.4 \\
\hline $\begin{array}{l}\text { Conditions under which an American } \\
\text { could be deprived of his citizenship: }\end{array}$ & & & & & & \\
\hline Mentioned none & 18.2 & 10.0 & 21.1 & 35.0 & 4.8 & 8.1 \\
\hline Mentioned treason & 31.8 & 50.0 & 63.2 & 25.0 & 52.4 & 48.6 \\
\hline $\begin{array}{l}\text { Mentioned Communists or other } \\
\text { disloyal persons } \\
\text { Mentioned refusal to fulfill } \\
\text { citizenship requirements; } \\
\text { paying taxes, etc. }\end{array}$ & 22.7 & 40.0 & 10.5 & 15.0 & 57.1 & 29.7 \\
\hline
\end{tabular}

(and LLL) group much more frequently accepted as good Americans individuals who believe in socialism, or who were once in the Communist party, or who do not believe in God. Those in the Symbolic and $\mathrm{HHH}$ groups were the least likely to respond without qualification that such persons could be good Americans. On the other hand, the Functional group was less likely to indicate that someone who does not know the Con- 
stitution, or who believes in segregation, could be a good American. The Normative group stands out most clearly in its acceptance of someone who does not know the Constitution or who believes in segregation. Finally, on a summary index, members of the Symbolic and $\mathrm{HHH}$ groups were more likely to reject a person on four or more of these characteristics as not being a good American.

With some exceptions, these results may in part be summarized as indicating that those in the Symbolic group were much more conservative in their views of the content of the national role, that they emphasized values such as freedom and a belief in God, and were more exclusive in their view of who is a good American (though the latter may be an artifact of the criteria we presented).

The last item in this group to which differential responses were made asked the respondent whether he could think of conditions under which an American should be deprived of his citizenship. Those in the Functional group were more likely to respond spontaneously that treason-attempts to undermine or overthrow the political system-is such a condition, as were members of the Normative group. On the other hand, those in the Functional group least often mentioned Communists or other disloyal persons. Also the Normative group somewhat more frequently mentioned failure to meet citizenship requirements, i.e., violation of laws.

These results indicate that members of the Functional group were more liberal in their views of a "good American," those in the Symbolic group much more conservative in their definition. In addition, it provides some independent confirmation of the emphasis which the Normative group places on fulfilling legal and normative requirements, and on failure to meet such require- ments as the distinguishing criterion of a "bad American." Finally, there is a striking parallel between the response patterns of those in the Symbolic group and the members of the HHH group; this suggests that the Symbolic orientation is a major component of the substantive meaning of our $\mathrm{HHH}$ classification.

A separate but related series of items asked the respondent whether he had heard of, and, if so, if he approved of, the activities of seven organizations: American Medical Association (AMA); National Association for the Advancement of Colored People (NAACP); Americans for Democratic Action (ADA); United Fund; John Birch Society; House Committee on Un-American Activities (HUAC); and National Committee for a Sane Nuclear Policy (SANE). Table 9b presents the items in this series which elicited differential responses. There is a strong liberalconservative difference in the response pattern obtained. The members of the Symbolic group more often approved of conservative organizations such as the Birch Society and HUAC, and disapproved of the liberal NAACP and SANE; the Functional group more frequently approved of the latter and disapproved of the former. The Normative group is again intermediate between the Symbolic and Functional.

\section{UNIQUE CHARACTERISTICS}

One way to obtain information about the content of the respondent's view of America and the "American way of life" is to see how it differs from his perceptions of other countries. One group of items used to elicit information concerning perceived differences consisted in presenting, individually, a series of institutions or areas of life, and asking the respondent whether and how the US differed in this respect from other countries. The items in this group which were answered differentially are shown in Table 10. 
TABLE $9 \mathrm{~b}$

Attitudes Toward Organizations

\begin{tabular}{|c|c|c|c|c|c|c|}
\hline \multirow[t]{2}{*}{ Response } & \multicolumn{6}{|c|}{ Percent endorsement } \\
\hline & SYM & NORM & FUNC & LLL & HHH & OTHER \\
\hline $\begin{array}{l}\text { Heard of five or more out of } \\
\text { seven organizations }\end{array}$ & 68.0 & 90.0 & 95.0 & 80.0 & 90.4 & 71.6 \\
\hline $\begin{array}{l}\text { Approve of the activities of } \\
\text { the NAACP }\end{array}$ & 40.9 & 30.0 & 78.9 & 45.0 & 38.1 & 29.7 \\
\hline Disapprove of the activities of the & 260 & 600 & 790 & 550 & $72 ?$ & 297 \\
\hline Disapprove of the activities of HUAC & 4.5 & 10.0 & 47.4 & 25.0 & 9.5 & 10.8 \\
\hline Approve of the activities of SANE & 13.6 & 20.0 & 42.1 & 10.0 & 28.6 & 13.5 \\
\hline $\begin{array}{l}\text { Supported none of the conservative } \\
\text { organizations }\end{array}$ & 9.1 & 30.0 & 73.7 & 25.0 & 19.0 & 10.8 \\
\hline
\end{tabular}

Those in the Functional and LLL groups were less likely than the remaining groups to mention religious freedom as a difference in religion in this country, while the members of the Functional group were much more likely to mention religious pluralism. In the area of child-rearing, the Functional group more frequently perceived it as less strict in the US; those in the Normative group were least likely, by a small percentage, to mention this. To the question whether there is any special US music or art, members of the Normative and Symbolic groups most frequently responded "No" and were less likely than those in other groups to mention American "popular culture," e.g., jazz, rock and roll. Finally, the members of the three "pure" integration groups were more likely than members of the other three groups to perceive the US as differing on at least three dimensions.

ASSASSINATION

As discussed earlier, questions were included on the assassination of President

TABLE 10

Unique Characteristics

\begin{tabular}{|c|c|c|c|c|c|c|}
\hline \multirow[t]{2}{*}{ Response } & \multicolumn{6}{|c|}{ Percent endorsement } \\
\hline & SYM & NORM & FUNC & LLL & HHH & OTHER \\
\hline \multicolumn{7}{|l|}{$\begin{array}{l}\text { What is different about religion } \\
\text { in this country: }\end{array}$} \\
\hline Religious freedom & 45.5 & 40.0 & 15.8 & 10.0 & 33.3 & 40.5 \\
\hline Religious pluralism & 0.0 & 10.0 & 36.8 & 5.0 & 23.8 & 13.5 \\
\hline $\begin{array}{l}\text { Differences in the way we raise our } \\
\text { children: we are less rigid, less strict }\end{array}$ & 18.2 & 10.0 & 36.8 & 25.0 & 14.3 & 18.9 \\
\hline $\begin{array}{l}\text { What is different about music } \\
\text { and art in the US? }\end{array}$ & & & & & & \\
\hline No, nothing & 40.9 & 60.0 & 21.1 & 15.0 & 9.5 & 18.2 \\
\hline Popular culture & 4.5 & 10.0 & 36.8 & 25.0 & 33.3 & 21.6 \\
\hline $\begin{array}{l}\text { Perceives the United States as different } \\
\text { from other countries on three or } \\
\text { more of ten dimensions }\end{array}$ & 45.4 & 50.0 & 36.8 & 20.0 & 19.1 & 21.6 \\
\hline
\end{tabular}


TABLE 11

Assassination Items

\begin{tabular}{|c|c|c|c|c|c|c|}
\hline \multirow[t]{2}{*}{ Response } & \multicolumn{6}{|c|}{ Percent endorsement } \\
\hline & SYM & NORM & FUNC & LLL & HHH & OTHER \\
\hline $\begin{array}{l}\text { Attended special services or memorials } \\
\text { following the assassination }\end{array}$ & 9.1 & 10.0 & 26.3 & 25.0 & 33.3 & 0.0 \\
\hline $\begin{array}{l}\text { The loss of someone very close and } \\
\text { near: very deepest feeling }\end{array}$ & 59.1 & 30.0 & 36.8 & 10.0 & 28.6 & 35.1 \\
\hline $\begin{array}{l}\text { Sorrow for Kennedy's wife and } \\
\text { children: very deepest feeling }\end{array}$ & 40.9 & 30.0 & 47.4 & 20.0 & 42.9 & 48.6 \\
\hline $\begin{array}{l}\text { Felt angry that anyone should do } \\
\text { such a terrible deed: a deep or } \\
\text { very deepest feeling }\end{array}$ & 81.9 & 50.0 & 89.5 & 55.0 & 66.7 & 77.8 \\
\hline $\begin{array}{l}\text { Worry about how the US would } \\
\text { carry on without its leader: } \\
\text { never occurred to me }\end{array}$ & 31.8 & 10.0 & 15.8 & 40.0 & 19.0 & 35.1 \\
\hline $\begin{array}{l}\text { Thought that the President had brought } \\
\text { it on himself: crossed my mind }\end{array}$ & 9.1 & 20.0 & 5.3 & 30.0 & 33.3 & 10.8 \\
\hline $\begin{array}{l}\text { Felt ashamed that Kennedy's assassination } \\
\text { could happen in our country: very } \\
\text { deepest feeling }\end{array}$ & 40.9 & 40.0 & 36.8 & 25.0 & 57.1 & 43.2 \\
\hline
\end{tabular}

Kennedy; these were taken from a survey made by the National Opinion Research Center (Sheatsley and Feldman, 1964) immediately following that event. In all, some twenty questions in the present study dealt with the respondent's reaction to and behavior following receipt of the news that President Kennedy had been killed.

In sixteen of these items, the respondent was presented with a statement describing some reaction to the assassination. For each he was asked to choose the one of four alternatives which best described his feelings: "Very deepest feeling," "Felt quite deeply," "Crossed my mind," and "Never occurred to me." The interviewee was given a card on which these four were listed, to which he could refer as he responded to each statement.

The assassination items to which the groups responded differentially appear in Table 11. It is interesting that members of the Functional, LLL, and HHH groups were somewhat more likely than members of the other three groups to have attended special services or memorials for President Kennedy.

Members of the Symbolic group much more frequently reported that the sense of loss of someone close was their very deepest feeling, while members of the LLL group were least likely to so respond. Sorrow for Kennedy's family was reported to be a very deepest feeling by about the same percentage of each group except the Normative and LLL. Also, anger was reported as a very strong reaction by a high proportion of all groups, but more frequently by the Symbolic and Functional (and Other) groups. Those in the LLL group were least likely to have worried about how the country would carry on (i.e., a higher percentage of them indicated this concern did not occur to them); those in the Normative group were most likely to have worried about this at some level of intensity. Very few reported that the thought that Kennedy had brought it on himself was a deep or very deepest feeling; it never occurred to most of the 
sample. However, it did occur to some and apparently differentially. It was least likely to have "crossed my mind" to members of the Functional group, most likely to those in the HHH group. Finally, feeling ashamed that it happened was a deepest feeling of numerous respondents, though less often in the LLL group and most often in the HHH group.

Emotional reactions (e.g., anger, sorrow) thus appear to have been especially strong in the Symbolic group. They most frequently reported such reactions, and the LLL group least frequently had such reactions at a deep level. The latter seems to be indicative of a lack of active involvement by members of this group. The Normative and Functional groups showed no particular pattern in their responses to these items.

\section{ATTITUDES TOWARD DEFENSE POLICIES}

Many items included in the schedule were designed to obtain information as to the relative importance the respondent places on military power and the need for military defense. The items in this category to which the score groups responded differently are indicated in Table 12.

The first item established a hypothetical situation in which the respondent had to choose between two candidates for President of the United States: one who stated that the most important thing facing America is "to win the Cold War against Communism around the world," and one who said it was "to do away with poverty and improve conditions here at home." The majority of each group responded that they would support a candidate who emphasized internal conditions, except for the HHH group, in which a large percentage would support the Cold War candidate. On a two-choice item that asked whether the safety and happiness of the American people or the protection of freedom throughout the world was more important, the Normative group slightly more often than the Symbolic and Functional selected the former, while those in the HHH group did so much more frequently. A differential concern with a powerful military is evident; the majority of the Symbolic and Normative groups believed that a powerful military is more important than individual freedom and prosperity, while 85 percent of the Functional group believed the latter is more important.

A large majority of those in the Symbolic and Normative groups believed the US is "pretty strong and safe," while members of the Functional (and LLL and HHH) group were more likely to choose the other alternative presented, that "some things seriously threaten us." There was no variation in the types of things mentioned as threats. Consistent with this finding, only one member of the Functional group indicated that the US is doing everything possible to prevent war; the members of this group much more frequently responded spontaneously that increased educational and cultural exchanges are something the US could be doing.

With regard to questions concerning demonstrations against nuclear testing, it is interesting that members of the Normative and Functional groups were more likely to report that they had heard of such demonstrations, with those in the Symbolic group least likely to so report. The Functional group, when asked what kinds of people they think engage in such activities, much more frequently responded that they are sincere and dedicated individuals (the remaining categories consisted of various negative categorizations). Finally, the members of the Functional group were the only ones who indicated personal support for these demonstrations with any frequency.

When asked how they felt about the US 
TABLE 12

Attrifudes Toward Defense Policies

\begin{tabular}{|c|c|c|c|c|c|c|}
\hline \multirow[t]{2}{*}{ Response } & \multicolumn{6}{|c|}{ Percent endorsement } \\
\hline & SYM & NORM & FUNC & LLL & $\mathrm{HHH}$ & OTHER \\
\hline $\begin{array}{l}\text { Would support a Presidential candidate } \\
\text { who wanted to prosecute the Cold Wa } \\
\text { over one who favored improved } \\
\text { internal conditions }\end{array}$ & 36.4 & 30.0 & 31.6 & 20.0 & 66.7 & 45.9 \\
\hline $\begin{array}{l}\text { Believes that a powerful military force is } \\
\text { more important than individual } \\
\text { freedom and national prosperity }\end{array}$ & 63.6 & 70.0 & 15.8 & 50.0 & 85.7 & 70.3 \\
\hline $\begin{array}{l}\text { Believes protecting the safety and } \\
\text { happiness of the American people is } \\
\text { more important than protecting and } \\
\text { extending freedom throughout } \\
\text { the world }\end{array}$ & $\begin{array}{l}27.3 \\
797\end{array}$ & $\begin{array}{l}40.0 \\
800\end{array}$ & 21.1 & 35.0 & $\begin{array}{l}57.1 \\
52.4\end{array}$ & 40.5 \\
\hline $\begin{array}{l}\text { Anything the US could be doing to } \\
\text { make war less likely: }\end{array}$ & & & & & & \\
\hline $\begin{array}{l}\text { No, doing everything now } \\
\text { Increase exchanges }\end{array}$ & $\begin{array}{r}40.9 \\
4.5\end{array}$ & $\begin{array}{r}30.0 \\
0.0\end{array}$ & $\begin{array}{r}5.3 \\
42.1\end{array}$ & $\begin{array}{r}30.0 \\
0.0\end{array}$ & $\begin{array}{r}23.8 \\
4.8\end{array}$ & $\begin{array}{r}24.3 \\
8.1\end{array}$ \\
\hline $\begin{array}{l}\text { Has heard of people picketing or } \\
\text { demonstrating against nuclear testing }\end{array}$ & 50.0 & 80.0 & 84.2 & 70.0 & 61.9 & 59.5 \\
\hline $\begin{array}{l}\text { The kinds of people who participate } \\
\text { in such demonstrations are: } \\
\text { Sincere, dedicated people } \\
\text { I personally support such demon- } \\
\text { strations }\end{array}$ & 9.1 & 20.0 & 47.4 & 25.0 & 14.3 & 10.8 \\
\hline $\begin{array}{l}\text { We are spending too much for arms } \\
\text { and defense } \\
\text { It is too much because we don't need } \\
\text { a defense plant that big }\end{array}$ & 27.3 & 0.0 & 52.6 & 45.0 & 9.5 & 10.8 \\
\hline $\begin{array}{l}\text { It is about right because: we need } \\
\text { to continue to develop weapons to } \\
\text { maintain our military strength } \\
\text { and supremacy }\end{array}$ & 27.3 & 40.0 & 15.8 & 5.0 & 28.6 & 35.1 \\
\hline $\begin{array}{l}\text { The best use we can make of money } \\
\text { saved due to disarmament is: }\end{array}$ & & & & & & \\
\hline 1. Increase public welfare programs & 9.1 & 20.0 & 42.1 & 30.0 & 23.8 & 13.5 \\
\hline 2. Reduce the government debt & 45.5 & 20.0 & 0.0 & 25.0 & 52.4 & 37.8 \\
\hline 3. Build highways, schools, etc. & 18.2 & 40.0 & 36.8 & 30.0 & 9.5 & 32.4 \\
\hline $\begin{array}{l}\text { We do not pay enough attention to } \\
\text { our military leaders }\end{array}$ & 36.4 & 20.0 & 21.1 & 5.0 & 42.9 & 32.4 \\
\hline
\end{tabular}


spending " $\$ 60$ billion a year on arms and defense," those in the Functional and LLL groups were most likely to feel that this was too much, with no one in the Normative group so responding. When asked for their reasons, members of the two former groups most often felt it was too much because US defense needs are not that great. (Those in the Symbolic group who felt it was too much all responded that waste and useless spending was the reason.) Normative group members most often felt our spending was about right because our defense needs required it. When asked to rank five possible uses of money saved due to disarmament (increase public welfare programs, increase foreign aid, reduce national debt, build highways and schools, and reduce taxes), those in the Functional group most frequently selected increased welfare programs as the best use, while those in the Symbolic and HHH groups most often selected reduction of the government debt. About one-third of each group, except Symbolic and HHH, chose the construction of additional highways and schools as the best use.

Finally, when asked how they felt about the power of the military, those in the Symbolic and $\mathrm{HHH}$ groups were most likely to feel we do not pay enough attention to our military leaders.

A heavy emphasis by those in the Symbolic group on military strength is evidenced in this analysis. They more often believed that a strong military is more important than individual freedom and national prosperity; that our defense spending is high because it is necessary; and that we do not pay enough attention to military leaders. At the same time, they more frequently felt we are strong and safe; those in the Functional group more often felt we are threatened, but that increased exchanges rather than a larger defense plant is the answer. Members of the
Functional group also showed greater support for disarmament. The HHH group appears to contain some of both kinds of emphasis, which is consistent with its members being high on all three of the scales, though it tends to parallel more closely the Symbolic group response pattern.

\section{ATTITUDES CONCERNING FOREIGN} RELATIONS

Several sets of items dealt with attitudes toward our relations with other nations. Those on which differences in responses were found across score groups are shown in Table 13.

One question asked what our government should do when foreign governments take over property and plants in those countries owned by US business interests. In spontaneous answers, those in the Functional group most frequently emphasized negotiation and peaceful settlement as the appropriate action, while no one in the Normative and only one person in the Symbolic group gave this response. In response to the question whether American investments overseas are the interest only "of certain American investors and businessmen or those of all Americans," members of the Normative group were much more likely to mention the latter. At the same time, members of the Symbolic and Normative groups slightly more often indicated that these interests have nothing to do with their own.

Several sets of forced-choice items were employed which dealt with US responsibilities in other parts of the world, foreign aid, relations with Russia, and relations with Cuba. Each set consisted of several statements with which the respondent was asked whether he "strongly agreed," "slightly agreed," "slightly disagreed," or "strongly disagreed." Members of the Symbolic group appeared to be more isolationist; they least 
TABLE 13

Attitudes Concerning Foreign Relations

\begin{tabular}{|c|c|c|c|c|c|c|}
\hline \multirow[t]{2}{*}{ Response } & \multicolumn{6}{|c|}{ Percent endorsement } \\
\hline & SYM & NORM & FUNC & LLL & HHH & OTHER \\
\hline $\begin{array}{l}\text { What should the government do about } \\
\text { confiscation of US business-owned } \\
\text { property abroad by foreign govern- } \\
\text { ments: try to settle peacefully, } \\
\text { negotiate }\end{array}$ & 4.5 & 0.0 & 52.6 & 20.0 & 14.3 & 16.2 \\
\hline $\begin{array}{l}\text { Whose interests are American invest- } \\
\text { ments overseas: the interest of all } \\
\text { Americans }\end{array}$ & 31.8 & 90.0 & 36.8 & 35.0 & 38.1 & 43.2 \\
\hline $\begin{array}{l}\text { Do these interests have anything to do } \\
\text { with your own interests: no, nothing }\end{array}$ & 63.6 & 60.0 & 42.1 & 50.0 & 38.1 & 37.8 \\
\hline $\begin{array}{l}\text { Strongly agree that "we must concern } \\
\text { ourselves with problems in other } \\
\text { parts of the world" }\end{array}$ & 36.4 & 60.0 & 68.4 & 50.0 & 61.9 & 56.8 \\
\hline $\begin{array}{l}\text { Foreign aid: } \\
\text { Agree ( strongly or slightly) that we } \\
\text { should only give aid to countries } \\
\text { who favor our policies }\end{array}$ & 68.2 & 50.0 & 31.6 & 50.0 & 66.6 & 56.7 \\
\hline $\begin{array}{l}\text { Agree (strongly or slightly) that we } \\
\text { should give aid to any country in } \\
\text { the world which needs it }\end{array}$ & 50.0 & 30.0 & 63.1 & 65.0 & 42.9 & 40.5 \\
\hline $\begin{array}{l}\text { Agree (strongly or slightly) that } \\
\text { economic aid programs should } \\
\text { be run by UN }\end{array}$ & 40.9 & 20.0 & 57.9 & 60.0 & 52.3 & 51.3 \\
\hline $\begin{array}{l}\text { Relations with Russia: } \\
\text { Strongly disagree that the only } \\
\text { way to preserve our way of life } \\
\text { is to attack Russia }\end{array}$ & 72.7 & 100.0 & 89.5 & 80.9 & 71.4 & 81.1 \\
\hline $\begin{array}{l}\text { Agree ( strongly or slightly) that } \\
\text { "We should accept being equal } \\
\text { in power with Russia" }\end{array}$ & 54.6 & 80.0 & 89.5 & 55.0 & 61.9 & 56.7 \\
\hline $\begin{array}{l}\text { Strongly agree that "The US must } \\
\text { be willing to run any risk of war } \\
\text { that may be necessary to prevent } \\
\text { the spread of Communism" }\end{array}$ & 27.3 & 0.0 & 5.3 & 15.0 & 57.1 & 40.5 \\
\hline $\begin{array}{l}\text { Responded to two or more items in } \\
\text { a direction indicating aggressive- } \\
\text { ness toward Russia }\end{array}$ & 22.7 & 20.0 & 0.0 & 25.0 & 42.9 & 45.9 \\
\hline
\end{tabular}

often strongly agreed that the US should be concerned with problems in other parts of the world.
The various pure groups responded differentially to three items concerning foreign aid. First, those in the Symbolic and $\mathrm{HHH}$ 
TABLE 13 (Continued)

\begin{tabular}{|c|c|c|c|c|c|c|}
\hline \multirow[t]{2}{*}{ Response } & \multicolumn{6}{|c|}{ Percent endorsement } \\
\hline & SYM & NORM & FUNC & LLL & HHH & OTHER \\
\hline $\begin{array}{l}\text { Relations with Cuba: } \\
\text { Strongly disagree that we should } \\
\text { invade Cuba now, using American } \\
\text { supplies and troops }\end{array}$ & 50.0 & 70.0 & 84.2 & 55.0 & 33.3 & 43.2 \\
\hline $\begin{array}{l}\text { Agree ( slightly or strongly) that } \\
\text { "We should help the anti-Castro } \\
\text { refugees with supplies and training } \\
\text { but send no American troops" }\end{array}$ & 50.0 & 10.0 & 36.9 & 60.0 & 57.1 & 59.4 \\
\hline $\begin{array}{l}\text { Agree ( slightly or strongly) } \\
\text { that "We should resume trade } \\
\text { relations with Cuba" }\end{array}$ & 27.3 & 30.0 & 47.3 & 25.0 & 14.3 & 21.6 \\
\hline $\begin{array}{l}\text { Responded to four or more } \\
\text { items in a direction indicating } \\
\text { aggressiveness toward Cuba }\end{array}$ & 36.4 & 10.0 & 26.3 & 30.0 & 61.9 & 49.6 \\
\hline
\end{tabular}

groups most frequently endorsed limiting our foreign aid to countries which favor our policies, while those in the Functional group least often endorsed this. On the other hand, members of the Functional and LLL groups most frequently favored giving aid to any country which needs it, while the Normative group least frequently agreed with this. Finally, those in the Normative and Symbolic groups were less likely to favor economic aid programs being run by the UN rather than by individual nations; i.e., these individuals were most concerned about American loss of control over such programs.

In the area of relations with Russia, those in the Symbolic and LLL groups were least likely, members of the Normative group most likely, to disagree strongly that the only way to preserve "our way of life" is to attack Russia. The Functional and Normative groups were more likely to endorse the statement that the US should accept equality of power with Russia; the same groups were least likely to agree strongly that the US must run any risk of war necessary to block Communism, while the $\mathrm{HHH}$ group much more often strongly agreed with this. For each of the six items dealing with Russia, it was possible to designate either agreement or disagreement as an "aggressive" response; therefore, an index of the number of items each respondent endorsed in such a direction was constructed. No one in the Functional group answered two or more items in an aggressive direction, while those in the $\mathrm{HHH}$ and Other groups most often did so.

With respect to Cuba, members of the $\mathrm{HHH}$ and Other groups were least likely to disagree strongly that we should invade Cuba now, while the great majority of persons in the Functional group did so. At the same time, only one person in the Normative group and one-third of the Functional group endorsed aiding anti-Castro refugees; the remaining groups were more likely to favor such aid. Those in the Functional group were most favorable to resuming trade relations with Cuba, those in the $\mathrm{HHH}$ group least favorable. On a summary index constructed in the same fashion as the one dealing with Russia, members of the Normative group were least likely to endorse four or 
TABLE 14

Attitudes Toward Supranational Organizations

\begin{tabular}{|c|c|c|c|c|c|c|}
\hline \multirow[t]{2}{*}{ Response } & \multicolumn{6}{|c|}{ Percent endorsement } \\
\hline & SYM & NORM & FUNC & LLL & HHH & OTHER \\
\hline $\begin{array}{l}\text { Strongly agree that we should } \\
\text { immediately take steps toward } \\
\text { establishing a world government }\end{array}$ & 18.2 & 10.0 & 52.6 & 15.0 & 38.1 & 16.2 \\
\hline $\begin{array}{l}\text { Agree (slightly or strongly) that we } \\
\text { should give the UN more power }\end{array}$ & 31.8 & 60.0 & 89.5 & 35.0 & 47.6 & 70.0 \\
\hline $\begin{array}{l}\text { Agree (slightly or strongly) that we } \\
\text { cannot put too much faith in the UN }\end{array}$ & 68.2 & 40.0 & 31.6 & 40.0 & 57.1 & 59.4 \\
\hline $\begin{array}{l}\text { Agree ( slightly or strongly) that we } \\
\text { should not allow an international } \\
\text { body to tell us what to do if we } \\
\text { don't want to do it }\end{array}$ & 68.2 & 20.0 & 15.8 & 35.0 & 52.4 & 45.9 \\
\hline $\begin{array}{l}\text { We should stay in the UN because: } \\
1 \text {. It is doing a good job, serves a } \\
\text { necessary purpose }\end{array}$ & 22.7 & 20.0 & 47.9 & 15.0 & 23.8 & 32.4 \\
\hline $\begin{array}{l}\text { 2. It is the only international body, } \\
\text { our only hope }\end{array}$ & 13.6 & 20.0 & 42.1 & 40.0 & 38.1 & 24.3 \\
\hline $\begin{array}{l}\text { Favors giving Americans a choice of } \\
\text { serving in a UN army or the US army }\end{array}$ & 40.9 & 50.0 & 78.9 & 65.0 & 47.6 & 40.5 \\
\hline $\begin{array}{l}\text { All nations should take their disputes to } \\
\text { the International Court and accept its } \\
\text { decisions even if it decides against them }\end{array}$ & 54.5 & 90.0 & 89.5 & 60.0 & 71.4 & 75.8 \\
\hline $\begin{array}{l}\text { The US should accept the Court's de- } \\
\text { cisions even if they are against us }\end{array}$ & 22.7 & 50.0 & 73.7 & 50.0 & 61.9 & 51.4 \\
\hline
\end{tabular}

more items concerning Cuba in an aggressive direction, those in the $\mathrm{HHH}$ group most likely to do so.

Thus a more passive, negotiation-oriented stance by the Functional group appears in this analysis, though the Normative groupwhile not mentioning negotiation in property confiscation situations-seems even less aggressive toward Cuba. Members of the $\mathrm{HHH}$ group are by far the most aggressive in orientation in the present analysis.

ATTITUDES TOWARD SUPRANATIONAL ORGANIZATIONS

A number of items dealt with attitudes toward supranational organizations and US relations with such bodies. Those to which the various groups responded differentially appear in Table 14.

Given the results in the preceding section, it is interesting that the Functional and $\mathrm{HHH}$ groups were most likely to endorse strongly the establishment of world government. The members of the Functional group were much more likely to favor increasing the power of the UN, while those in the Symbolic and LLL groups were least favorable to such an increase. Consistently, the Symbolic group's members were most wary of putting too much faith in the UN, those in the Functional group least so. Finally, 
the Symbolic group most frequently agreed that we should not yield to an international organization's directives, while those in the Normative and Functional groups least often endorsed this statement.

One item asked whether the US should remain in the UN, and why or why not. While there was no large variation in the percentage who felt the US should, there was variation in the frequency with which two specific reasons were given. Members of the Functional group were most likely to indicate that the US should stay because the $\mathrm{UN}$ is effective, while those in the $\mathrm{HHH}$ and LLL, as well as the Functional, groups more often indicated that, while perhaps not effective, it is our only hope-a beginning. When asked whether young men should be required to serve in the US Army or given a choice between serving in a US or a UN force, those in the Functional and LLL groups most often favored giving Americans a choice between serving in the US Army or a UN Army.

The last two items in Table 14 dealt with the International Court. The first, after explaining its nature and purpose, asked the respondent which of two statements he agreed with: "Nations should not go to the International Court on disagreements which affect their vital national interests," or "All nations should take their disputes to the International Court and accept its decisions even if it decides against them." It can be seen that those in the Normative and Functional groups were most likely to endorse the latter, while those in the Symbolic and LLL groups were least likely to do so. The next item on the schedule asked which of these should be US policy toward the Court. Here, note that all groups were less likely to endorse accepting decisions adverse to US interests than they were to endorse the general statement; the relative degree of endorsement remained the same, with the exception that the Normative group was no longer more likely to endorse this than other groups.

Thus the Functional group was most favorable toward a strong international body and the United Nations, even at the cost of some US independence in decisions, while the Symbolic group was most concerned about preserving the latter. The $\mathrm{HHH}$ group fluctuated more in its responses to these items, and did not parallel any integration group; neither did the LLL group.

\section{ALIENATION ITEMS}

The final group of items are those which dealt with perceived personal effectiveness or competence; the absence of such a perception indicates passive alienation or apathy, at least in the sense that the person feels he has no influence over what happens to him. The items of this nature which were related to score group membership are shown in Table 15.

The first six items deal with whether the respondent feels he has any influence over the policies and actions of the government, i.e., his political effectiveness. With the exception of the first item, all were four-choice, closed-end items of the type discussed above. Each could be answered in a direction indicating that the respondent felt he had political influence or that he did not (e.g., agreement that working in groups is effective). A summary index was constructed of the number of items the respondent answered in a manner indicating perceived political effectiveness.

When asked if there was anything they could do personally to prevent war, those in the Functional group were much less likely to respond "no," and much more frequently responded that they could engage in various kinds of political activity. Those in the Sym- 
TABLE 15

ALtenation ItEMS

\begin{tabular}{|c|c|c|c|c|c|c|}
\hline \multirow[t]{2}{*}{ Response } & \multicolumn{6}{|c|}{ Percent endorsement } \\
\hline & SYM & NORM & FUNC & LLL & HHH & OTHER \\
\hline $\begin{array}{l}\text { Perceived political effectiveness: } \\
\text { Is there anything you can do personally } \\
\text { to prevent war: } \\
\text { 1. No, nothing } \\
\text { 2. Political activity: voting, } \\
\text { letter-writing }\end{array}$ & 59.1 & 70.0 & 26.3 & 20.0 & 14.3 & $\begin{array}{l}51.4 \\
18.9\end{array}$ \\
\hline $\begin{array}{l}\text { Strongly agree that working in a group } \\
\text { which takes stands on public issues } \\
\text { is a way that people like me can } \\
\text { influence the government }\end{array}$ & 36.4 & 20.0 & 47.4 & 25.0 & 38.1 & 35.1 \\
\hline $\begin{array}{l}\text { Agree ( slightly or strongly) that } \\
\text { voting is the only way people } \\
\text { like me can have any say about } \\
\text { how the government runs things }\end{array}$ & 54.5 & 40.0 & 26.4 & 30.0 & 71.4 & 48.6 \\
\hline $\begin{array}{l}\text { Agree (slightly or strongly) that } \\
\text { writing to Congressmen and public } \\
\text { officials is a way that persons like } \\
\text { me can influence the government's } \\
\text { action in foreign affairs }\end{array}$ & 72.8 & 60.0 & 94.7 & 85.0 & 76.2 & 91.9 \\
\hline $\begin{array}{l}\text { Agree (slightly or strongly) that people } \\
\text { like me have no say about what the } \\
\text { government does about foreign policy }\end{array}$ & 45.5 & 40.0 & 21.1 & 10.0 & 47.6 & 29.7 \\
\hline $\begin{array}{l}\text { Agree ( slightly or strongly) that foreign } \\
\text { affairs and national security matters } \\
\text { sometimes seem so complicated that } \\
\text { a person like me can't understand } \\
\text { what's going on }\end{array}$ & 95.5 & 60.0 & 78.9 & 65.0 & 90.5 & 86.4 \\
\hline $\begin{array}{l}\text { Responded to four or more of six items } \\
\text { in a direction indicating they perceive } \\
\text { themselves as having some political } \\
\text { effectiveness }\end{array}$ & 50.0 & 40.0 & 73.7 & 75.0 & 47.7 & 64.8 \\
\hline $\begin{array}{l}\text { Alienation: } \\
\text { Agree (slightly or strongly) that a person } \\
\text { has to live pretty much for today and } \\
\text { let tomorrow take care of itself }\end{array}$ & 54.5 & 20.0 & 26.4 & 45.0 & 28.6 & 51.3 \\
\hline
\end{tabular}

bolic and Normative groups were most likely to respond with the former, least likely to respond with the latter.

It can be seen that, on the summary index of perceived political effectiveness, the Func- tional and LLL groups were most likely to view themselves as effective. Thus, members of the Functional group most often strongly endorsed working in groups as an effective influence on the government, were 
TABLE 15 (Continued)

\begin{tabular}{lllllll}
\hline \multicolumn{1}{c}{ Response } & \multicolumn{5}{c}{ Percent endorsement } \\
\cline { 2 - 7 } & SYM & NORM & FUNC & LLL & HHH & OTHER \\
\hline $\begin{array}{l}\text { Strongly agree that these days a person } \\
\text { doesn't really know who he can } \\
\text { count on }\end{array}$ & 45.5 & 10.0 & 0.0 & 5.0 & 4.8 & 24.3 \\
$\begin{array}{l}\text { Agree ( slightly or strongly) that it's } \\
\text { hardly fair to bring children into } \\
\text { the world the way the future looks }\end{array}$ & 40.9 & 0.0 & 10.5 & 20.0 & 14.3 & 24.3 \\
$\begin{array}{l}\text { Responded to three or more items in a } \\
\text { direction indicating alienation }\end{array}$ & 54.5 & 10.0 & 10.5 & 35.0 & 28.6 & 37.8 \\
$\begin{array}{l}\text { Nothing in the news this past year } \\
\text { especially worried me }\end{array}$ & 22.7 & 20.0 & 0.0 & 40.0 & 19.0 & 18.9 \\
$\begin{array}{l}\text { Nothing in the news this past year } \\
\text { made me feel especially good }\end{array}$ & 54.5 & 40.0 & 15.8 & 35.0 & 33.3 & 24.3 \\
\hline
\end{tabular}

least likely to agree that voting is their only means of influence, were more likely to view letter-writing as valuable, and were less likely to agree that they have no say. The Normative, Symbolic, and $\mathrm{HHH}$ groups viewed themselves as least effective in these terms. Those in the Symbolic and $\mathbf{H H H}$ groups were most likely to agree that such matters seem so complicated they do not understand them (but so did a high percentage of the Functional group's members).

A final set of six items, also four-choice, can be interpreted as indicating personal alienation; these were taken from a study by Tumin (1958). The score groups showed variation in their responses to three of these items. In terms of their responses to these items, the Symbolic group was the most alienated from the political and social system. Members of this group were much more likely to agree that one has to live for today, to agree strongly that one does not know who he can count on, and to believe it is not fair to bring children into the world. Interestingly, the Functional and the Normative groups were least alienated and least likely to agree with the above statements.
Finally, to an open-end question asking whether anything in the news especially worried them or made them feel good, members of the Functional group were least likely to respond that nothing in the news especially worried them or made them feel especially good, i.e., they were most likely to recall specific things to which they reacted in these ways. The Symbolic group was most likely to respond that nothing made them feel particularly good, the LLL group that nothing especially worried them. (Recall that the assassination was during the year preceding the interview, and thus could have been mentioned in response to the latter.)

It would seem, then, that the functionally integrated most often perceive themselves as politically effective and are lowest in feelings of alienation, as measured by these questions. The symbolically integrated are most likely to feel alienated, and among the least likely to feel effective in exercising political influence.

\section{Conclusion}

With some exceptions, the pure-groups analysis is surprisingly consistent with the 
results of separate comparisons of high and low scorers on each individual scale. ${ }^{10}$ These comparisons verified and strengthened the relationships found in the present analysis. In this sense, the pure-groups analysis is a fairly comprehensive representation of the entire set of data.

In general, the data are supportive of the overall formulation and the specific hypotheses upon which this study is based. We have fairly clear evidence of the strong affect that characterizes the symbolically involved person, e.g., from the questions dealing with the assassination. He does indeed give high ranking to the role of national compared to other roles, and our data suggest that he is less tolerant of behavior or values that deviate from role prescriptions (cf. Table 9a). Similarly, the normatively involved person's concern with general norms is evidenced in many of his responses, e.g., that violators of norms are not "good" Americans. There is also evidence of his tendency to accept policies that he views as generally agreed upon, e.g., the amount spent by the US for defense (cf. Table 12). As expected, the normatively committed are more likely to be working class people.

The data support most clearly our conceptualization of the functionally committed. These respondents are, in fact, upper-middle and upper class individuals; they have the highest incomes and highest status jobs, and they are the most educated in the sample. Their responses to a number of questions indicate an emphasis on political and social responsibilities as the primary elements of the national role, and they are better informed about national organizations and

10 The latter analyses are not reported here in the interest of brevity. The results of these analyses are reported in DeLamater (1966), available from the Center for Research on Conflict Resolution, The University of Michigan, Ann Arbor, Michigan 48104. more likely to remember events in the news (cf. Table 15). This high level of support for the hypotheses is even more encouraging in view of our impression that the Functional scale was the poorest of the three.

Moreover, the three groups do show the expected differences in attitudes toward supranational organizations. The symbolically committed respondents are the most negative in their reactions toward the UN and the International Court, and the functionally involved are the most positive. The Normative group occupies an intermediate position. On other issues of foreign policy there were consistent differences between the Symbolic and Functional groups, with the symbolically committed taking a more traditional nationalistic position. The Normative group showed a variable pattern, sometimes more conservative than the Symbolic group, at other times much less so.

These data are of course only suggestive because of the small number of cases and the imprecision of the measuring instruments. Moreover, the findings are subject to varying interpretations. For example, it is possible to explain the relationship between functional involvement and openness to international cooperation as simply a product of higher levels of education and information. There is some reason, however, for believing that both educational level and a responsible position in the bureaucratic structure facilitate functional involvement and that these two variables interact. With a larger sample the complex relationships of educational level, economic status, position in the bureaucratic structure, functional orientation toward the nation, and attitudes toward international affairs could be ascertained.

Another major issue is the nature of the HHH and LLL groups (consistently high or consistently low on all types of involvement) relative to the three "pure" groups. The 
LLL group does not appear to be alienated. In fact, it is probable that there were no alienated persons in our sample; perhaps it was these people who refused to be interviewed. What then do they represent? Some of the data suggest that the HHH and LLL groups are opposite poles of a dimension, perhaps a dimension of liberalism-conservatism which is somewhat independent of the nature of commitment, one which cuts across the Symbolic, Normative, and Functional groups. The LLL are liberal, well-educated, etc., while the HHH are uniformly the most aggressive conservative group in the "puregroups" analysis.

A third problem has to do with the relationships between our three types of commitment and the relative compatibility of various kinds of mixtures. In general, there is greater incongruity between functional and symbolic commitment than between the normative and either of the other types, though a few individuals in our sample were high on all three. Normative acceptance of the national system can be readily combined with either a functional or a symbolic orientation without logical difficulty. Perhaps this is the reason the polarization of opinion occurred between the symbolically and functionally committed groups whereas the normative individuals sometimes were intermediate in position to the other two and sometimes much closer to one than the other. Our theoretical position is that any one of these three types can bind the individual into the social system, that the typology applies to the process and not necessarily to the specific individual, but that for many people there may be a preferred mode of integration.

In fine, this report of a field study suggests the importance of further critical ex- ploration of the dimensions of nationalism which will take into account (a) the emotional attachment to symbolic values and their indicators, (b) the acceptance of the normative demands of the system as legitimate, and (c) the perceived rewards from system membership. These three dimensions should relate differentially both to attitudes on domestic policy and to attitudes on foreign policy.

\section{REFERENCES}

Bell, Daniel (ed.) The Radical Right. New York: Doubleday-Anchor, 1963.

DeLamater, John. "On the Nature of National Involvement: An Empirical Study." Ann Arbor, Mich.: Center for Research on Conflict Resolution, 1966.

Durkhen, Emile. The Division of Labor in Society (tr. by George Simpson). New York: Free Press, 1952.

Gullford, J. P. Fundamental Statistics in Psychology and Education (3rd ed.). New York: McGraw-Hill, 1956.

KaTz, Daniel. "Nationalism and Strategies of International Conflict Resolution." In H. C. Kelman (ed.), International Behavior. New York: Wiley, 1965. and Robert Kahn. The Social Psychology of Organizations. New York: Wiley, 1966.

- Herbert C. Kelman, and Richard FLACKs. "The National Role: Some Hypotheses about the Relations of Individuals to Nation in America Today," Peace Research Society (International) Papers, 1 (1964), 113-27.

Kelman, Herbert C. "Patterns of Personal Involvement in the National System: A Socialpsychological Analysis of Political Legitimacy." In J. N. Rosenau (ed.), International Politics and Foreign Policy (2nd ed.). New York: Free Press, 1969.

Sheatsley, Paul, and Jacob Feldman. "The Assassination of President Kennedy: Public Reactions," Public Opinion Quarterly, 28 (Summer 1964), 189-215.

Tumin, Melvin M. Desegregation: Resistance and Readiness. Princeton, N.J.: Princeton University Press, 1958. 